CRITICISN OF THE METHODS OF CHRISTIAN MISSIONS

IN CHINA FRON A SOCIOJOGICAL FOIIT OF VIEW

by

Dora Otis $\underset{n i t c h e l l}{\text { Nit A.B. }}$

SUBNITTED IN PARTIAI FULFILI UNT OF THE

REQUIREMVEITS FOR THE DEGRE OF

MASTER OF ARTS

in the

GRADUATE SCHOOL

$$
\text { of the }
$$

UNIVERSITY QF MISSOURI

1916. 


\section{TABLI OF COITEIVTS}

Introduction

1. Social Effects of Missions

2. Other Contributing Influences in Social Change

3. Extent of Writer's Personal Knowledge of China

4. Inaccuracy of Chinese Statistics

Chapter I. Chinese Family Iife

1. The Chinese House

2. Patriarchal System, Filial Piety and Ancestor Worship

(1) Size of Family

(2) Control of Farily and Property

(3) Corporate Responsibility

(4) Ancestor Worship

(5) Filial Piety

(6) Conservatism

(7) Christian Home Separoted from Clan

(8) Christian Attitude toward Ancestor Worship

(9) Freedom and Individual Responsibility

(10) Originality of Chinese Christians

3. Separation of the sexes and the Seclusion of Woman

(1) Purpose of Separation of Sexes

(2) Rules of Chinese Scciety

(3) Betrothal by Parents

(4) Seclusion of Woman

(5) Recent Changes 
(6) Attitude of grissionaries

4. Early Betrothals

(1) Disadvantages of Early Betrothals

(2) Methods of Missionaries

5. Darly lariages

(1) Age at Marriage

(2) Influence of Education

6. Status of voman

(1) As Shown in Proverbs, Names, Characters

(2) No Will of Her Own

(3) Unworthy of Association with Wen

(4) Iames not to be Mentioned

(5) Christian Influence

7. Concubirage

(1) Prevaleice of

(2) Reasons for

(3) Cermony for

(4) Status of Secondary Wife

(5) A Chinese View of Concubinage

(6) Methods of Christian Church

(ry) Heed of Schools for Secondary Wives

8. Sex Immorality

(1) Prevalence

(2) Refuges for Fallen women

(b) Necessity of Attacking this Evil

9. Divorce

(1) Causes for Divorce 
(2) Prevalence

(3) Attitude of Church

10. Slavery in the Home

(1) Prevalence

(2) Reasous for Slavery

(3) Slaves, How Secured

(4) Treatment

(5) Teaching of the Church

(6) Slavery Forbidden by Goverment

(7) Need of Slave Refuges

11. Infanticide

(1) Prevalence in the Past

(2) Reasons for Infanticide

(3) Effect of Missionary Teaching

(4) Foundling Homes

(5) Prevalence of Infanticide How

(6) Three Methors of Missions

12. Foot Binding

(I) Origin

(2) Reason for Continuance

(3) Method of Pinding

(4) Pain caused by Foot Binding

(5) Effect on Health and Homes

(6) Manchu Attempts to Suppress

(7) Missionary Hesitancy

(8) Mission Schools Forbid Foot Binding

(9) Anti-Foot Binding Societies

(10) Present Conditions 
13. Suicide of Women

(1) Prevalence

(2) Causes

(3) Methods

(4) Help Given by Medical Missionaries

(5) Effect of Christianity

Chapter II. Educational Conditions

1. Educational Conditions in the Past

(1) The School and Social Frogress

(2) OId Examination System

(3) Purpose of This System

(4) Conservatism of the System

(5) Application to Existing Conditions

(6) Influence on Schools

(7) Bribery in Examinations

2. Educutional Systern Reconstructed

(1) Dissatisfaction with the Old System

(2) The Emperor's Reforms

(3) Empress Dowager's Suppression of Reform; Her Reforms.

(4) The New System of Schools

(5) Curricula of New Schools

(6) The Teaching Force

(7) Incompetency of peachers

(8) Discipline

3. Influence of lissions in this Reconstruction

(I) Furnished University presidents 
(2) Indemity School

(3) Mission Schools Gave Chinese Teachers

(4) Text Books

4. Present Work of Mission Schools

(1) Superior to Government Schools

(2) Course of study

a. Chinese Classies

b. Bible

c. Ingiish

d. Science

e. Over crowding of Curriculum

(3) Manual Training

a. Pingtu Industrial Work

b. Kind of Industrial Training Teeded

c. Changing Incustrial conaitions

(4) Need of Iormal Schools

5. Other Fethods of Bducating the Public

(I) Nerrspapers

(2) Public Lectures

6. Education of Vomen

(1) General Illiteracy

(2) Reasons for Illiteacy

(3) Opposition to Ilission Schools

(4) First Mission Schools

(5) Class of Students

(6) Self support

(7) Change of Chinese Attitude

(8) Schools for Higher Class Chinese 
(9) Increasing Popularity of Schools

(10) First Native School

(11) Empress Dowager's Reforms

(12) Need of Irained Teachers

Chapter III. Sanitation and Hygiene

1. Ignorance of Chinese Doctors

2. Contagious Diseases

3. Nedical Missions

4. Stamping out the Ineumonic Plague

5. Progress of Medical Missions

6. The Woman Doctor in China

7. Rockefeller Foundation for Medical Work

8. Education of the General Public

Chapter IV. Industrial Conditions

1. The Poverty-Stricken Condition of China

(1) The Beggars

(2) The Foverty Iine

(3) The Causes of Poverty

a. Not Lack of Industry

b. Not Lack of Resources

c. "Squeezing"

a. Famines

(4) The Effect of Poverty on Social Life

2. Methods of Missions

(1) Philanthropic

a. Chinese Cheritable Institutions

b. hristian haritable Institutions 
(2) Isucetional

a. Famine Relief

b. Afforestation

Chapter V. Opium

1. Introduction into China

2. Edict of 1729

3. Comissioner Sin

4. First Opium far

5. Second Opium Var

6. English Government Honopoly

7. Opium Cultivation Iegalized

8. Spread of Use of Opium

- Affect of Oxium Smoking

10. Missionary ifforts to Help Individuals

11. Church Rules

12. Agitation in England

13. Chinese Anti-opium Societies

14. Temorial to Impress Dowager

15. The Empress Doweger': Edict

16. hange in the Moral Fibre of China

17. The Difficulties of the Task

18. rreaty with England

19. Success in China

20. Shanghai Anti-opium Comission

21. New Treaty with England

22. Opium Stored in Treaty Ports

23. Present Conditions 
Chacter VI. Political Corruption and other Immorality

1. "Squeezing":

(1) Causes for "Squeezing"

(2) Stealing of I'axes

(3) The Salt Iaxes

2. Bribery

(1) Methods of Missionaries

(2) Christian statesmen

3. Untruthfulness

(1) Among Ion-Christians

(2) Among Christians

4. Gambling

(1) Preval ence

(2) Causes

(3) Native Desire to Suppress

(4) Example of Christians

(5) Need of ider Service

Conclusion

1. Social Results of Iissions

2. UItimate outcome 
CRITICISI OF THE NIETHODS OF CHRISTIAN IIISSIONS

IN CHINA FROM A SCOIOI,OGICAL POINT OF VIEW

\section{IMTRODU C ION}

Christian Missions have been a poweful agency toward the social transformation of mission lands. While it has been as a rule the avowed purpose of missionaries to work for indivialuls, they have from time to time been drawn into the struggle against social evils. It is the purpose of this thesis to critioise the methods by which missionaries have attacked the colossal social evils of Cina. The motive for Christian mission work is religious. While it is my personal opinion and the opinion of all who engage in mission work that their success is due to this fact, it is not the province of this thesis to deal vith that important phase of mission work. It is the province of this thesis to deal with the purel social results of missions and to criticise the methods of missionaries from the point of view of their influence on the social life of the Chinese people.

Iy personal knowledge of China is Iimited to one province. hile I have traveled in other provinces, it is imposible to acquire an intimate knowledge of a people. so different from us as are the Chinese by a few days or a few months visit. The people in the various sections of China are as different from each other as are the 
people in the various sections of turope. They differ in custons, in lenguage, in appearance and in aisposition. That province of China with which I am most familiar is Kiangsu, particularly the cities of Shanghai and Soohow. I resided in the former city one year and in the latte: four years. I have heen dependent upon my reading for my knowledge of the rest of China.

Unfortunately no accurate Chinese statistice are otainable. No general census has ever been taken. In 1911 an estimate of the number of families was taken and this number wa mutiplied by five and one half which was supposed to be the average number in a family. This brought the number of the population down to $329,54 \%, 000$ which is several million less than the $400,000,000$ to whom reference has so often been made. Iverywhere we find the same inaccuracy in statistics. 


\section{CHAFTER I. \\ CHINESE FAMIIY IIFE}

The Chinese House.

The Chinese house is usually only one story high and is never more than two stories. The houses of rich people often spread over a great area, sometines covering several acres. The women's apartments are in the rear and the men's in the front of the house. The rooms are alvays built around open courat, which are often quite pretty with green trees and plants.

The Patriarchal System, Filial Piety and Ancestor Worship. In America when a young man marries, he and his wife go apart and establish a new household, the financial burdens of which he bears. In China a young man does not have to wait until he can support his wife before he marries, for he takes her into his faternal hove, and his father provides for both his son and his new daughter-in-law. Wives for the other sons are also brought under the paternal roof. When their sons in turn become about twenty years old, wives for them are found and brought to the home, where there is areat cornbination of complicated relationships: grand parents, parents, uncles older than the father, uncles younger than the father, cousins who are sons of uncles older than the father, cousins who are daughters of uncles older than the father, cousins who 
STREET

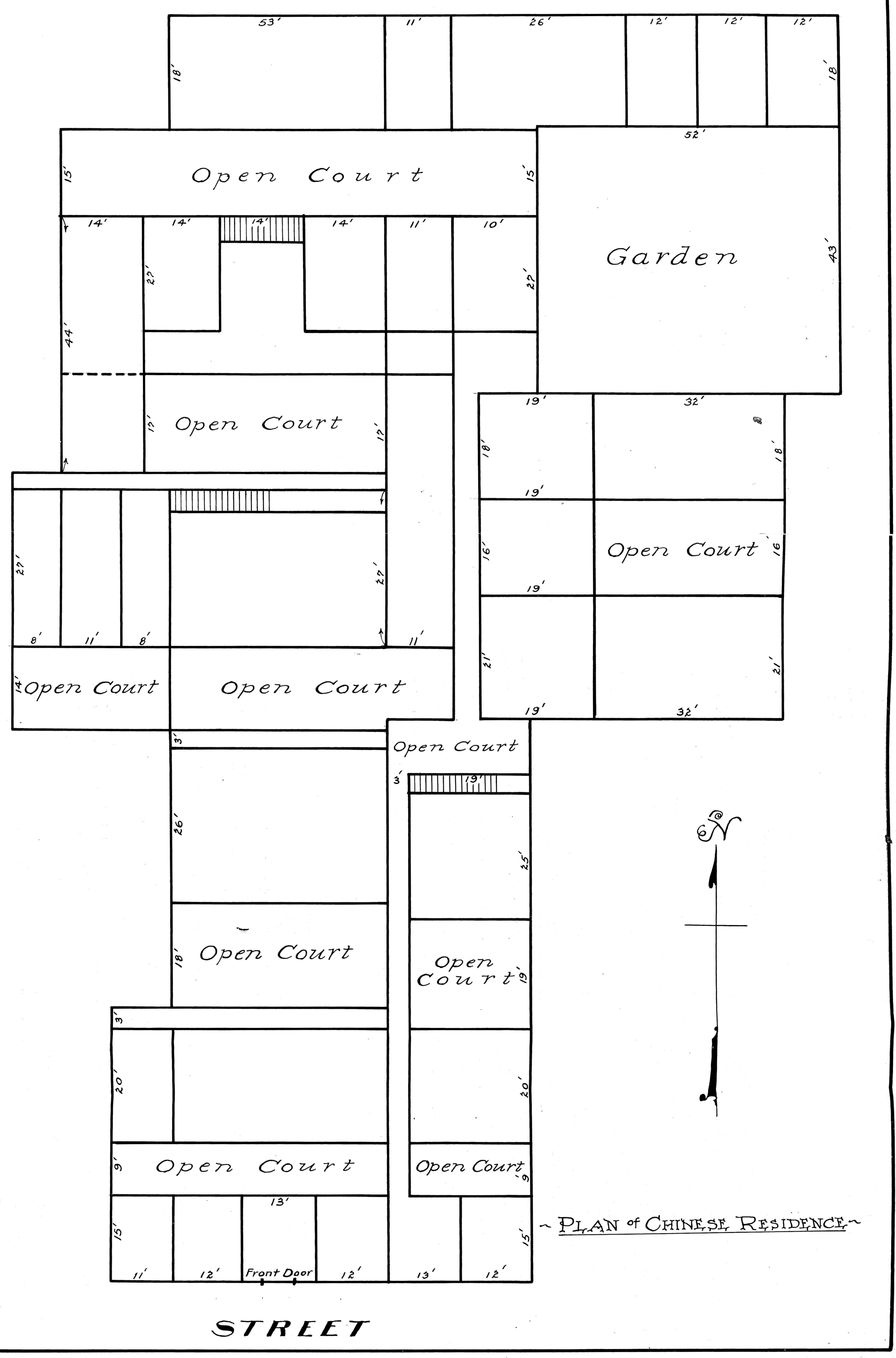


are sons of unles younger than the father, cousins who are daughters of uncles younger then the father, aunts who are wives of uncles older than the father, aunts who are ives of uncles younger than the father, and so on ad infinitum, each nember having particular titles showing his exact relationship to every other member of the clan. Whe grandither if living is the ruler of the farnily. At his death his oldest son receives the scepter and the money bag. All property is omned in common. Every one who draws a salary brings it to the common head, tho receives it and uses or invests it at his own aiscretion.

ut more important than the law of cormon property in the Chinese family is the law of corporate responsibility. Every memer of the family is responsible for the misdemeanors of every other member. Frequentiy an entire family has been punished for the crime of one member. 1 sonetimes the neighoors also aro hela responsible as in the following case: "A man, aided by his wife, flogged his mother. The pair were flayed alive, and the grand uncle, uncle, two elder rothers, and the head of the clan were executed; the neighbors on either side, the father of the woman, and the head representative of the It erary degree the man held were flogged and banished; the prefect and the district ruler were temrorarily degraded; and the child of the offenders was given another name." 2

1. Smith, chinese Characteristics, Chap. XXII. 2. Capen, soc. Progress in ission Lands, p. 210. 
The family is further bound together by the conmon vorship of ancestors. ncestor worship is practically universal among non-Christian Chinese. The living provide for the dead and in turn rely upon their sons to provide for their own cornfort and happiness in the next world. Hence the great desire for sons which has its influence upon all life in china.

While living, the crandfather reveres the great grandather; the father, the grandfather; the son, the father. The younger generation serve and sacrifice for the older generation, even to the extent of shedding their blood and cutting off their flesh for the nourishment of their garents in sickness. Confucius praised filial piety and gave twenty-four examples of ancient heroes who showed such devotion. And since his time thousands of others who have exhibited filial piety have been eulogized and celevated throughout the land. The son must not only serve and sacrifice for his parents, but he does not shon proper filial respect if in any way he excels them. Kings have been known to abdicate the throne hecause they did not want to reign longer than their fathers had reigned.

In this family system we see the causes of the conservatism for wich china has been noted. A young man with any initiative was restrained by deep seated, century ola customs. It was improper for him to cio anytining his father had not cone. It was dangerous for 
him to attempt anything new. Grand parents, parents, uncles, cousins, etc., put a stop to any new procedure, for which they might be held responsible. lhe son must oby the father, and the father the grandfather. y the $t$ ime a man gained $h i s$ freedom from $l i v i n g$ paternal authority, he was so old that he had lost all power of initiative, and haci forgotten about any divergent impulses which he might have had in his youth. Gven then he was still bound by his auty to do as his ancestors had done.

While trying to retain in the Christian family all that is good of the Chinese filial care and love of parents, missionaries have encouraged the formation of a new home whenever a Christian young man and young woman are married. The new family cannot have decent privacy in the clan house. When surrounded by a host of conservative relatives, they cannot train their children according to the ne light which they have received. The family customs ancideals in regard to the status of woman are contrary to Christian ideals. So the young Christian couple go apart and have a small home of their own where they attempt to Iive according to the new ideals of home life wich they have learned. They give up ancestor worship. The Roman Catholic pope decided against ancestor vorship in the bull of 1742. Protestants missions have stood against ancestor worship for religious reasons from the beginning.

3. Catholic Encyclopedia of Missions, Vol. III, p. 668. 
This stand which has been taken against ancestor worship has lessened the power of conservatism and has increased the freedom of the individual.

The spirit of Christianity itself favors the development of personal freedom and personal responsibility. In the recent political upheaval in china many of the leaders were christians. It has been estimated that seventy-five per cent of these revolutionists in 1912 were Christians.

From experience in teaching chinese young women. I have iittle doubt that the conservatism and lack of originality which has been so characteristic of the Chinese is the result of this system of the patriarchal family with its ancestor worship, filial piety, common property and corporate responsibility, and that liew China, if imbued with the sense of personal freedom and individual responsibility which Christianity inspires, will exhibit originality of thought and action comparable with that of western nations, if not superior to it.

Separation of Sexes and seclusion of tomen.

The purpose of the very strict separation of the sexes which exists in China is the preservation of the virtue of womant. It is based on the principle that the average man cannot be trusted with a woman.

4. Headland, Home Iife in China, p. 89.

5. Brown, The Foreign Missionary, p. 278. 
Accordingly after a girl is eight or ten years old (formerly it was at the age of four or five) ${ }^{6}$ she is kept from all association with the opposite sex, even from association with her own brothers except on formal occasions.? It is not proper even to mention the names of members of the other sex. The women have separate apartments in the rear of the house. If one of them wants to call on a 1 dy friend, she goes through the streets in a closed chair chd $^{8}$ is admitten to the ladies' apartments of the friend's house by a side door. When a man comes to see his friends, as he approaches the main entrance, if he is well-bred he gives a warning cough, so that he will not come upon any of the feminine members of the home unawares? Ladies may attend theaters but have separate sections there, and it is not thought proper for them to glance toward the men!" If occasion should arise, as it rarely does, for a man to hand a lady some needed article, he must not give it to her airectly, but must lay it dow on the table in front of her, so that there will be no possibility of their hands touching!" It is even bad form for a lady to sit in a chair where a man has been sitting. The school girls at InTyeire School (Shanghai) derived a great deal of

6. Current Iiterature, 33:100 J1. 102.

7. Ross, The Changing Chinese, r. 184.

8. Ross, The Changing Chinese, p. 182.

9. Missionary Review of Morld, 24:524-6. 10. Headland, Court Iife in China, p. 264.

11. Ross, the changing chinese,p. 184. 
amusement from one of the more doring of their number who sat down in the chair which my chinese teacher, who was a man, had occupied an hour before.

Because of this absolute separation of the sexes there is no opportunity for a young man and a young woman to become acquainted with each other before betrothal or narriage. The young feople are betrothed by their parents, who themselves rake use of a "middie man" or "go-between". These match makers are proverbially untruthful, and the outcone is sometimes surpising to everybody concerned. A Chinese woman, whom I knew in soochor, married off her son, who was an idiot, to an unsuspecting young lady. On some occasions brides and grooms discover on their weding day that they have been married to fersons afficted with loathome disease. ${ }^{3}$

Even after marriage there is practically no companionship between the bride and eroom. Whey do not eat together, out together or talk to each other more than is necessary. If he goes away for a time and desires to write to her, he must not address the letter to her, but to his parents who receive it and deliver it to her. It is a disgrace for hin to shov any affection for her. Evan at her deati he must not shom any grief. This separation of the sexes has brought about the seclusion of woman. Arthur H. Smith very aptly

12. "Iie like a ratchnaker." "Ien matchmakers, eleven liars."

13. Whe statutes require thot parents shall furnish proof that their son and daughter are neither diseased, deformed nor under or ov ge. But this law is not always obeyed. See Douglas, society in hina, $p$. 192. Also Current Lit. 33:100. 
compares the existence of woman in China to that of a frog in a well!" For women there have been very little source of enlightenment. And there has been little opporturity for collective activity such as might have prevented the spread of the opium and the foot binding evils.

Within recent years there has been marked change in regard to the seclusion of women and the separation of the sexes. This is true especially along the coast where there is more foreign in luence. But missionaries have found it very advisable to delay the change as long as cossible. Frof. Homer B. Hulbert, after many years of life in Korea, declares that "under existing moral conditions, the seclusion of woman in the Far East is a blessing and not a curse, and its immediate abolishment would result in a moral chaos rather than, as some suppose, in the elevation of society."15 Neither the young men nor the young women are prepared for the immediate abolishment of the separation of the sexes. They both need to be developed in moral character and control, and in the rules of etiquette necessary for association between the sexes. An older Chinese woman sagely remarked to some of her younger sisters who were chafing under the restraint, "American young men and wornen know from babyhood what it is proper that they should do and

14. Smith, Chinese Village Iife, p. 262.

15. Quoted in Brown, The Foreign Missionary, p. 278. 
say in each other's presence, but you have not the slightest conception of these things."

The following story illustrates the helplessness, lack of. self de fendence and self confidence, which Chinese young women exhibit as a result of their secluded and dependent lives. A young man in one of the mission schools in Soochow desired to ask for the hand of a young woman in marriage whom he had seen at. church, but to whom he had not spoken." 's she was an orphan under the care of the missionary, he came to the missionary and made his wishes know to her. The missionary in turn went to the young lady and stated the case to her. Whereupon the young lady held up her hands helplessly and said, "I always was afraid this would happen to me!" "But," the missionary said, "What do you want to do about it?" The girl answered, "Oh, just as you say."

While the missionaries hope that the abolition of the separation of the sexes in China will not come be-fore Chinese young people are prepared for it, they themselves are taking a few steps away from such absolute secaration as has prevailed in the past. To us in America these steps seem very small indeed. Now photos are exchanged before betrothal, and the wishes of the two young people are consulted. If the betrothal is favored by both parties, the negotiations are then completed. After this the young man and the young voman may write to each other. Fut except in rare cases, as 
for instance wen the young man and the young woman are teachers in mission schools in such foreign settlements as Shanghai, there is no conversation whatever between ther until after marriage. This is not ellowable in grood Chinese christian society vet. one of my young lady friends, a Christian living in wusih, was seen talking to her fiance on the street, and almost lost her reputgtion in consequence.

It is difficult for Americans to realize how fan these voung peorle are from knowing how to conduct therselves under the new conditions which are crowding in upon them. Many missionaries have learned to their sorrow and reset the grave dangers that attend the change. The domfall of the wall between the sexes is inevitaly coming. The task of the missionary is to retard that domfall as long as kossible in order that there may be more time for the preparation of the youth in roral character and control for such intermingling of the sexes as shall be rnutually beneficial.

Early Betrothals.

Chinese girls and boys are frequently betrothed by their parents when they are exceedingly young. This is becase male progeny is so desirable for ancestor worship and the parents want to ke sure to hre all necessary arrangements made in the event of their ow death. Some chilonen are even betrothea nefore birth by the two mothers, 
with the provision of course that one turns out a girl and the other a boy. These eariy betrothels are unwise for several reasons. The position of the tro families often changes after such an engagement is made, and by the time for the veding the young man or the young lady finds himself or herself engreed to one much below his or her social station. The character of the boy and erirl cannot be now at so early a date and frequenty distressing combinations are made!" sometimes on account of sickness the mental growth of one of the parties is arrested, but even this does not make the ketrothal less onligatory.'7 And the chinese hetrothal is very binding indeed. It is easier to secure a divorce in America than it is to break a betrothal in china.

$$
\text { While missionaries canot lirge their pupils to }
$$
beeak betrothals that have been made in childhood, if the girl herself through the independence of thought and the self respect which ahe ho gained in the mission school refuses to abide by such a contract, the missionaries sive her their sympathy and assist her in carrying out the necessary arrangements for such a breaking of custom. Missionaries also teach Chinese Christian parents to delay netrothal until the children have become nore mature, ${ }^{\prime 8}$ and also to select for Christian young people Christian mates.

16. Smith, Chinese Village Life, $x .26 \%$.

17. Ross, The Changing Chinese, f. 194.

1. Peport of Edin. Con. Committee, $x .387$. 
Early karriages.

Early marriages are also desired by the Chinese because of their desire for male progeny. It is not necessary to wait until the young man can support his bride for they both become a part of the paternal family and are supported by it. The average age of girls at marriage is from sixteen to seventeen years. Foreign influence has raised this age in peking to eighteen, in shanghai and Wuchow to twenty, in swatow to from sixteen to eighteen, and in Chungking to from seventeen to eighteen where formerly it was from fourteen to fifteen. "At twenty practically all girls, save prostitute, are wives and five sixths of the young men are husbands." 19

Such early marriages are undesirable because they interfere with the education of the young people and because they are one of the causes of the rarid increase in population, where the economic pressure is already too great. Nissionary influence is against these early marriages. Christian and government educotion for girls is doing much to raise the age of marriages. 20

The Status of Woman.

While in Chinese literature there has been some exaltation of the Chinese woman, in real life there is little besides contempt for her. Proverbs in common 19. Ross, The Changing Chinese, p. 97. 20. "In 1909 the oard of Education in Fekine ruled that students in the government schools should not marry under twenty in the case of girls and twenty-two in the case of hoys." Ross, p. $9 \%$. 
use shed light on the attitude of the Chinese toword her. "Iighteen goddess-like daughters are not equal to one son with a limp." "A young wife should be in her house but a shedow and an echo." 2 "ihe names of little pirls also ofter denote their undesirability, such for instance as, "Want-a-boy," "Too-many-girls," "Come-a-boy" and "Iittle Trouble. ${ }^{22}$ A study of the chinese written character also discloses chinese thought regarding woman. The "woman" radical doubled means "to wrangle," tripled. it means "to intrigue, "secuction, "fornication." ${ }^{23}$ In fact the chinese consider that of the two princirles of which the vorld is rade, "Yang, "I ight and good, and "Yin," darkness and evil, the former is male and the latter is female. Tre symbol of these two gri ciples is seen everywhere.

$$
\text { Confucius said, "It is a }
$$

law of nature that women should be

\section{Yin}

kept under the control of man, and not allowed any will of her own." Woman

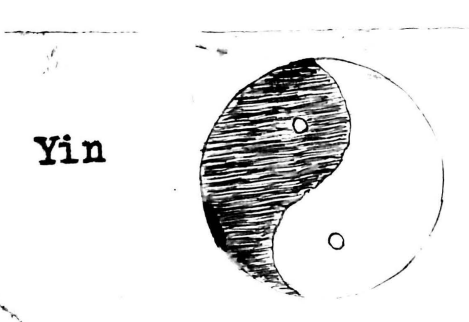
in jouth must obey her parents, when married she must obey her husbend and his parents, in old age in the event of the death of her husband she must obey her son. "ithin the home she has some authority, as there she rules her daughters and daughters-in-law.

She is not consicered worthy of sitting at the

21. Singh. S. I., Edin. R. 216:163-86.

22. Miss. Review of the World, Apr., 1915, F. 305.

23. Smith, Chinese Characteristics, F. 246. 
table and partaking of food with her husband and sons, nor of appearing on the street in company with them. Recently in Shanghai a leading citizen, when remonstrated with in regard to this custoril, answered,"Oh, we are iriproving gradually. We are willing now to ride up and down the streets with the courtesans of Foochow street. Perhaps so e time we will be willing to appear with our wives." It is not even good form for a man to mention the name of his rife. He speaks of her as his son "Ah-ling's mother," or as his "Fu-nvung" (subservient person), or as his "dull thorn" or "mean one within the gite. i2y

Probably the example of the respect which Chinese missionaries pay their wives has had more influence than anything else in reaking down the feeling of contempt for women in China. The example of rative Christians is having its influence also. The Young Men's Christian Association has been particularly careful in its teachines regaraing the respect due women. In Shanghai the Chinese Y. I. A. A. secretaries are often seen sitting with their wives at fublic entertainments. A Marichu nobleman's wife said of her hushand, "Since he joined that Association (Y. I. C. A.) he hes treated me kindly for the first time in his life."25 The Chinese Christians learn respeot for woman from their Bible study. ¿4. Louglas, Society in China, p. wl2. 25. Niss. R. of W. June, '15, p. 468. 
Those in schools learn it from anglish literature. The educaticn of woman has elevated her and has made her more worthy of respect.

Concubinage.

Concubinage is commonly sanctioned by the practice of the Chinese people. The Anperor was allowed to have eighty-four vives. President Yuan shi-k'ai has nine vives and fourteer concubines. Any man who can support more than one wife has the privilege of doing so. But the percentage of men who do this is comparatively small, heing according to Chinese estimates ony from three to five cercent.7 This is ecause not rany men are financially able to support more than one vife.

The reason for this system of concubinaee is by no means an exces in the number of women over the number of ren. Io accurate statistics of these numbers are obtainable because, as every one at all conversant with thịngs chinese, knows no general census has ever been taken in the Celestial Empire. In 1910 a census of Feking was taken, which gave 500,819 adult men and 256,538 adult women. ${ }^{28}$ In Kianesi it is estimated that there are one fourth rore males than fomales. ${ }^{29}$ It is rroboly true elsewhere also that there is an ercess of rales owing to the practice of female infanticide. 26. Smith, Chinese Village Life, p. $29 \%$. 27. Ross, The Changing Chinese, $x .189$. 26. International Year Book, r. 160. 29. Niss. R. of W., 1911, p. 786. 
One of the principal reasons for the system of concubinage in China is ancestor worship and the necessity of having sons to carry on the family worship. The worship ry daughters is not efficacious as is the worship by sons. Unless a man after his death has a male descendant to burn incense, paper money, paper houses and other make-helieve conveniences in his honor, he must suffer vant in the other orld and go about hegeing from his more fortunate companions. While with us religion is sometimes an "other world fire insurance policy, "with the Chinese it is an "other world endowment policy." It would be difficult to overestimate the influence of ancestor worship in China. It fermeates the entire social structure and colors a large part of the thoughts and plans of the Chinese people.

Accordingly from the Chinese rint of view it is the most serious situation if there is no son in the family. More than one son provides security against accident, and grandsons and great grarisons are most desirable adaitions to the family line.

So if there is no son in a fanily, especially if it is a well-to-ao family, the husband takes a secondary wife. Sometimes this is done with the consent of the first wife, for she too wants a son to worship before her teblet. This secondary wife does not belong to the better class of reople. She has probably been a slave or an inmate of a house of ill fame. She is brought 
into the new home with very little ceremony, does not ride in the red sedan chair of the bride and does not worship heaven and earth as does the first wife. She only worships the ncestral tablets. In south china she merely hands a cuf of tea to her adrire and he after drinking the tea passes the tray hack with a sum of money on it wrapped in red paper.

When the concubine is brought into the home, although she has an axpipent to herself, she is under the cominion of the first wife. If any man should attempt to make a secondary wife the equal in authority or honor with his first wife, he would be severely punished by the magistrate or by his first wife's fumily. Should any childen be born to the secondary wife, her status is raised, but the children are not considered her own. They remain with her in her apartment but they are spoken of as the first wife's children and in case of the death of the first and secondary wives they worship before the tablet of the first wife instead of before that of their own mother.

Polygamy is one of the great causes of the general debaserent of woman in China. It is also fatal to the peace of the home. The men know this when they bring the se ondary wives into the horne and it is customary for them to sympathize with each other because of the "bitterness which they hove to eat" in consequence. There 30. Doolittle, Social Iife of the Chinese, p. 76. 
is usually constant jealousy and continuous strife.

Robert $\mathrm{E}$. Speer interviewed a well known Chinese philanthropist and social reformer, lr. Yung Tao, on this subject and his answer was as follows: "The most dangerous point of Chins is this, that most people look only after pleasures. In order to get a pleasure they rust secure some money either by squeezing or by gambling. When by chance they get money, their first thought is to marry a concubine. The more money they heve the more concubines they will marry. The chinese can do business as well as others, but they are so engaged with this system of concubinage that they are always satisfied with a little becalse they want all the tire they can have with their concubines. This concubine system has existed in China for thousands of years, but in the olden times only the higher classes of people could have concubines. Now, however, this thing has spread so widely that it has Gone to nearly all classes. ......... The Chinese families of the high class have so many wives, kicking each other, heing jealous of each other, holdirig each other down. ........ The poor husband has to support them. That is why when nything co es to their hand they grasp the money or squeeze it out of others. I have looked into this very minutely and every business that is in the hands of people having nany wives is never successful."31

31. Quoted in International Reviev of lissions, Apr. 16,p. 191. 
The christian Church has stood firmly against the system of concubinage. Ito uhristian may sell his daughters to be concubines. Lo Christian may take a secondary wife. If a man already has more than one wife when he becomes a Christian he rast live with only one of them. He is not compelled to take the first one but he $e^{i s}$ allowed the rrivilege of choosing which one he will take for his wife, as the first one was not his own choice originally but vas selected for him and married to him by his parents. But he is compelled to supcort his other wives and children just as he did refore hecoming a Christian.

The exarncle of happy Christian nores is already a fower in China. Nany progressive non-Christian Chinese and leacing business men now are showing an earnest desire to separate from their secondary wives. There are so many of these discarded secondary wives now in China that the Bdinburgh Conference Continuation Committee, meeting in shanghai last year, recomenced the establishment of schools by Christian missions for these women where they could be educated and taught to be self supporting. 32

This cormittee also recormencied the formation of a chinese "lomen's Alliance "to carry into effect the abolishing of early narriages and the practice of taking secondary wives, and that this alliance should urge the government to incorporate these reforms in the law of the 32. Report of Edin. Continuation Committee, Shanghai, p. 393. 
Republic." In view of the great victories secured in the abolition of the opium and foot binding evils aoes it not seem possible that such an alliance might, by means of public lectures, the dissemination of literature, and the pover of cersonal example and personal touch in due time bring about these so much needed reforms?

Sex Immorality.

There are no statistics showing the prevalence of sex irmorality in China. There can be no doubt that it is exceedingly prevalent. Shanghai is rotten, ${ }^{3}$ and from all reports many other chinese cities are just as bad. Mission workers have been able to do little in combating this heinous social evil, other than to teach their church members to live pure lives, and to extablish refuges for flien women. lany of these fallen women heve been sold into lives of shame by their parents in times of financial distress. Some have been kidnapfed when children. The Door of Hope in Shanghai was estaklished as a refuge to which any such woman could go. Hotices are posted in different parts of the city to the effect that refuge will be offered to any fallen woman at this institution. There is an industrial defartment in connection with this institution and the women are taught to be self suprorting. There are four other such

33. It is estimated that there are 20,000 Chinese prostitutes in Shanghai. Brown, The lissionery, p. 116. 
refuges under mission auspices in china, but these are far too fer to meet the need. Chinese authorities have proved ready to help these refuges and some Chinese have even started similar homes in Peking and Tientsin.

Sex immorality in china is a social evil of great magnitude with which the future church will have to cope. It is condemned in the teachings of the Founder of Christianity and is destructive of the sacred Ife of the home, and must be fought by the unitea church.

Livorce.

There are seven reasons for which a man may divorce his first wife in China. These are: (1) Unfilial conciuct tovard his parents, (2) Not giving hirth to a son, (3) Adultery, (4) Jealousy, (5) Lexposy or other virulent disease, (6) Talkativeness, (7) thieving. ${ }^{34}$ But these causes are not consicered sufficient in three cases: (I) If she has no family to return to, (2) If she has passed through three years mourning for his firents, (3) If they have risen from poverty to affluence together since they were married. There are no grounds for a woman' obtaining a divorce from her husband, but she and her husbaid can obtain ${ }_{\Lambda}$ y mutual consent. There is really very little divorcing of first wives in china. The population presses so closely on

34. Headland, Home Iife in China, p. 119. Doolittle, Social Iife of the Chinese, f. 70. 
the margin of subsistence that the voman's family would probably have no way to support her if she was returned to them. ${ }^{35}$ The husband knows his wife's family would cause him no end of trouble. So many unpleasant things are likely to occur, that it is easier for him to obtain a secondary wife who is more to his liking and avid the company of his first wife as much as possible. This secondary wife may be discarded at pleasure.

Within the church the sacredness and the permanence of the ma riage tie are taught by the missionaries and by the native leaders. They allow divorce for only one cause. It is ereatly to be hoped that China will he able to steer clear of the great divorce problems of the United States.

Slavery .

Wile there is very little slavery in China outside of the homes, it exists to an appalling degree within the hores. ${ }^{36}$ The slaves are almost always girls-very rarely boys. Jach daughter of a vell-to-do family is iven one slave girl or more if the family will allow. This slave is her playmate in youth, her meid servant at her wedding, and accompanies her to her new home. If she is pretty she probably be omes one of the concubines of her mistress's husband.

35. Capen, Sociological Irogress in tission Lands, f. 110. 36. Kahn, Ind. 53: 1605-E, JI. 'II. 
The reason for this slavery is obvious. The Chirese woman "ith her "golden lily" feet has been unahe to take care of herself and her home. The slave girl waits upon her and even carries her about on her back if the mistress so desires.

Parents may sell their daughters to be slaves. They receive for them from ten to two hundred dollars each. 37 Extreme poverty soretimes drives them to do this, especially in times of famine. Sometimes they sell them for as low as fifteen cents each in famine times. Cometimes little girls are kidnapped to be sold as slaves. At other times they are given away by their owners. The treatment of the slave depends upon the character and disposition of the owner. A great many slaves are cruelly beaten and mistreated and afterwaras frequently are thrown out into the yard to die. 38 The slave has practically no legal protection. The penalty for the murder of a slave cannot be more than one hundred and seventy blows, while thet for killing a horse or an ox belonging to another is one hundrea blows. 39

The missionary's teaching of the brotherhood and spiritual equalty of man insires a spirit of freedom. Church memers are taught the wrongs of slavery and are encouraged to free their slaves. We hear however, that even among Christians there is still some slavery, although the condition of these slaves is considerably 37. Doolittle, Social Life of the Chinese, p. 498. 38. Dr. Kahn, Ind. 53:1605-8, JI. '11. 39. Douglas, Society in China, r. 349. 
amelioreted. Teaching in regard to slavery is not sufficiently strong and specific. An imperial rescript in 1910 forbade safery in China, prohibiting under any pretext the rurchase and sale of human eings.40 This edict is however, not enforced generally. The city of Canton has for idcen slavery and offers shelter and education to any excert the lind ho appeal for help. The blino are given over to the missionaries in that city to be cared for and educated in their institution for the care of the blina.

In two respects the methods of missions in regard to slevery might be bettered. (I) The evils of slavery should be exosed, and more determined efforts should be made to create fublic sentiment against slavery. (2) Refuges should be crovided where the freed slaves could receive education and be taught to become self supporting, altruistic members of society.

Infanticide.

The practice of infanticide has in the pest varlied in different localities. In Peking there wes practically none. Fukien was the province where there was most infanticide." Where wo more in centrel and south China than in the north and west. 42 No accurate statistics are obtainable, but it has been estimated that

40. Outlook, 95;285.

41. Douglas, cociety in China, p. 354.

42. Dennis, Chrigtian Iliss. and Soc. Prog., Vol. I, p. lag. 
in Fukien an average of forty ercent of the girl babies were thus murdered $4^{3}$ In 1877 Rev. C. Hartwell estimated that at Foochow "from thirty to seventy per cent of the female infants have been destroyed." 42 For the vicinity fo Amoy the estimates varied from ten to eighty fer cent of the girl babies. ${ }^{3}$

Boy babies were very seldom disposed of because they in time would be of financial ascistance to the family and because they vere so essential in the system of ancestor worship. But girl babies were unwarranted because already there vere too many mouths to feed. The unpleasent duty of binding her feet sdded to her undesirability.44 Girls had to be cared for until time for them to be married and then a doviry had to be provided for them. After the weding day the bride went to the home of her husband and becare a part of his family, only returning at rare intervals to visit her parents and never giving them enything in return for the money they had expended on her suffort. The girl was very exfensive and burdensome to the family.

So frequentiy she was killed at birth, either drowned, or exrosed, or burned alive.45 he was dromed in a bucket of water provided for the yurose in the event of the new horn baby's being a irl, or she was thrown into pond devoted to that use such as the one

43. Capen, Soc. Prog. in Miss. Lands, F. 15\%. 44. Dennis, Vol. I, f. 213,; Ross, The hanging Chinese,p. I78. 45. Doolittle, Social Iife of the Chinese, r. 495. 
in Amoy which was furished with a special sign: "Babies may be drowned here. "46 or she was exposed on sorie lonely island or rock, ty throm into a baby tower built for the purpose outsice the city. Iut burying alive vas considered the best method as in such case the next child would more probably be a son.45

The missioneries and Chinese Christians exly began to point out the cruelty and heartlessness of this practice. Pamphlets setting forth the inhumanity of the custom vere distributed. These had much influence in awakening the conscience of the people. Infanticide was of course, forbidden in Christian families and the influence of their example soon began to be felt. In Hankow non-Christian parents who had several daughters, when asked why they kept their daughters, answered, "We see that the Christians are keeping their girls, and e think perhaps we might be able to do the same."48

Eurthermore the raisionaries succeded in rescuing thousands of the exposed infants and flaced them in founding homes where they vere wil cared for until they were given out into families 49 to be adopted or reared as daughters-in-law. Later when fublic sentiment was developed to such an extent that the government began to

46. Jennis, Vol. I, p. 130.

47. Douglas, Society in China, p. 355.

48. The lonthly thes sener, June, $1897, p .160$, quoted in 49. Dennis, II, II, 278 . 278. 
legislate against infanticide, municiral authorities established similar founding homes, which were indeed far from perfect but indicated an advance step. I visited the native founding hore in Soochow and was informed that more than six hundred eirl babies were received there during a year. These were "famed out" to families in Soochow ara vicinity.

The Chinese with whon I talked on the subject of infanticide in soochow declared that at the rresent time there is no more infanticide in China. Their knomledge of China was however, very limited. It is practiced in secret even around Soochow, as missionaries itinerating in the country districts found the bodies of babies here and there who had evidentIy been murdered. 9 . A. Ross in 1911 wrote that some Chinese estimated that from one-twentieth to one-tenth of all girl babies in China are still killed.50

Iissionaries can use three methods in dealing With this evil: (I) Forbidding it in the christian constituency, (2) lieaching the chinese public the inhumanity of the custom, (3) Estahlishing model receiving stations with a system of "farming out" and adequate instruction in the care of these children. Such an institution as the one in soochow, if the care given was sanitary and hygienic, would be advisable, as babies cemot be raised in institutions.

50. Ross, The Changing Chinese, p. 193. 
Foot Binding.

One of the most widely known social evils of China has been the binding of the feet of the vomen. The beginnings of this custom are not recorded in history. There was no such custom at the time of Confucius. Some say that it began in the Tsi dynasty, A.D. 50I. Others say that it had its origin in the Tang dynasty, A.D. 975." Some of the Chinese say that it was done to make the women stay at home, but others told me that there was at one time a princess born with deformed feet, like a deer's feet, and that her father, the mperor, ordered all Chinese girls' feet to be bound so as to keep his daughter from embarrassment. Another legend has it that the stjle spread from a beautiful dancing girl, whose feet were described as "golden lilies, "who danced before the Ermperor.

What ever may have been the origin of the custom, the reason for its continuance was matrimonial. The Chinese have long been of the opinion that the goal of a girl's life is to be married and give birth to sons. For centuries chinese mothers had known that a girl with normal feet could not be well married. Ho respectable man would want her. With the exception of the lianchu women, the Hakka women, and in southern China many women of the laboring classes, for a woman not to have bound

51. Dennis, II, p. 355.

52. A nomadic class of eople in Kvangtung province. 
feet meant that she was a secondary wife, a bond maid, or a prostitute. The custom was almost irresistible because it ws so peculiarly entrenched in the social system. Accordingly when the little daughter was four or five years old long strips of bandage about two inches in width were bound around the foot, in the same manner in which a surgeon wraps a wounded foot, except the four small toes were folded back under against the sole of the foot, and the bandage, was drawn very tight, hending the toes down and bowing the foot, finally crushing and rreaking the bones of the inster and causing indescribable pain.

The Chinese girls suffer not only in childhood from bound feet. Throughout their lives they must stand and walk with their weight on their crushed and broken feet. They have been schooled not to mention the pain in their feet and their suffering is probably greater than we know.

Their general health suffers a result of their crippled condition, for of course with bound feet they cannot take much exercise. Wornen with bound feet cinnot properly care for their homes. This is one of the great causes of the unsanitary condition of Chinese homes. The Manchu rulers regretted this custom. ${ }^{53} \mathrm{Be}-$ fore the influence of Christianity was felt, the tmperor decreed that the custom should he suppressed." But there

53. Goadrich, The Coming China, p. 206.

54. Dennis, Vol. II, p. 353. 
was no public opinion to support the decrees and they had no influence whatever. "A quarter of a millemium of lartar rule had done absolutely nothing torard the elimination of foot binding." 55

$$
\text { At first Christian missionaries took no posi- }
$$

tive stand against the foot binding custom. 5 . They knew how deeply entrenched it was in Chinese social I ife and they thought it wisest not to interfere with it at first. They hoped thet the principles they taught would in time have their influence in abolishing a custom so cruel and inhuman.

Dut in the early seventies their opposition to it began to be more open. As early as 1870 a girls' school is heard of where all girls who rere admitted must unbind their feet. 58 other girls' schools with this requirement reathen heard of in various claces. 59

These schools rew stedily in enrollment until ractically al their space was filled, and in some instances waiting lists were kept of other girls willing to comply mith this requirement. These schools gained in prestige and their influence became powenful. When the Chinese--official and unofficial--saw the great advantages of the girls with unbound feet over those with

55. Snith, Village Iife, p. 26I.

56. Capen, oc. Frof. in Iss. Lands, y. 180.

57. Dennis, Tol. II, Y. 353.

58. Denris, Vol. II, p. 355 .

59. P. E. School in Peking; C. I. I. School in Wenchow, 1874; St. Mary S Hall in Shanghai; Presbyterian Boarding School in Shanghai; Hangcho: S. Preshy, Girls' (Con't p. 34 ) 
bound feet, it first began to occur to them that possibly there might sometime be a change. About this time Viceroy Chang said, "Woman with bound feet are not fit to be the mothers of soldiers." 60

There began also to spring up here and there anti-food-binding societies. The first of these of Which there is a record is the one in Amoy under the leadership of Rev. John Mackowan. This society began with a membership of over forty in 1874, some hinese and some foreign. It finally grew to a membership of over 1000 in the nineties.

In the nineties the movement took on new life. The Shanghai Missionary Association in 1893 appointed a committee "to deal with the whole business with full power to act." The chief result of the work of this committee s the organization of the Ilatural Foot Society. This society was made up of not only missionaries, ut also wives of consuls and other prominent foreigners, and had Mrs. Archibald Little, wife of a mer-

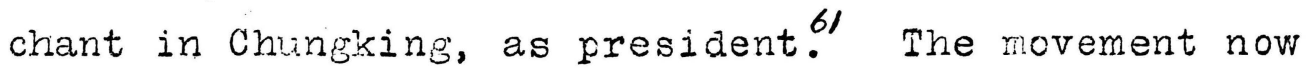
spread beyocnd the missionary circle and hegan to gain momentum throughout China.

Boarding School; Mctyeire School in Thanghai;

Tweiki Girls: School in Kiargai; anton Temale Seminary, 1890, 92 firls, only 5 bound; 1 . E. School in Janking: Boarding School of Foreipn Christian Miss. Soc. in Nanking; Tungchow Girls' High School, 32 pupils, only 4 bound; Iondon Miss. Soc. School in Peking, 37 pupils, only 1 bound; Bridgman school of American Board at Feking; Kiukiang Amer. Heth. Dpiscopal School. Dennis, Vol. II, p. 359.

60. Nartin, W. A. P., World's Work, l¿, p. 7845.

61. Dennis, Vol. II, p. 357. 
Anti-foot-binding societies sprang up everywere. one of the most vigorous of these vas at Chungking, the home of Mrs. Iittle, who has done more tomard the removal of this cruel custom vrobably than any other pe:son. This society in chungking was rade up of members of the four Irotestant lissions in the city. The methods of these societies were various. Iady nembers unbound their feet and promised not to bind the feet of their daughters. Fathers agreed not to engage their sons to girls with bound feet. Mrass meetings were held for discussion pro and con; prizes trere given for essays on foot binding; much literature ves distributed; a memorial was prepared to present to the zmperor sking his intervention; frizes were given for the neatest shoes made to fit normal feet; petitions mere presented to the Viceroys; poetry was written on the subject in Foochow and the poor and the blind were paid a small sum for repeating it on the streetg; quiet appeals were made to conscience; chur h members were urged not to bind their daughters' feet; sometimes they were forbidaen to; hyms on the subject were composed and sung; posters were rnde and posted in public places; heart felt prayers were offered by missionaries and native Christians.

In 1899 Dennis closed his account of the antifoot-binding movement in chine in the following manner: "It camot be said that foot-binding is to ny $n$ ticeable extent abolished in thet vast empire, yet it is manifestly 
true that nothing has ever so disturbed its sway over Chinese society as this same quiet missionary crusade. In time, perhaps much sooner than we expect, it will be entirely benished and despised as a relic of ignorance and barbarisr. When that day comes there can e no uncertainty as to who began the assault, and to whom the chief honor of the victory belonss." 62

The crusade was continued on into the Twentieth century. In 1906 there ves another imperial edict against foot-binding, the famous edict of the Impress Dowager. Tut the situation was not the same as it had been before. Iublic opinion had been aroused. The conscience of the people had heen awakened. The foot-binding custom was doomed.

It is true that at the present time most of the older women still have bound feet, for it does not help much to unbind them after they have been bound for twenty years. The majority of women now have bound feet, but their feet were bound in the last century, not in the present century. The question is not how many women have bound feet now, but how many little girls' feet are being bound at the present time. The percentage of these is small. The victory over the custom is won. In Christian schools the spirit against foot-binding is so strong that Girls whose feet r small because they have once been bound buy large shoes and stuff them with cotton to make

62. Dennis, Vol. II, f. 366. 
ther look as large as the feet of other girls. The government his follomed the exmple of the mission schools and has refused to amit girls mith bound feet in government schools. 63 "Th the rapid increase of the number of these schools the final low will be given to this custom. The question is settled in China. It is no longer agitated because the current of public opinion is against it.

Suicide of lomen.

Suicide is more comon in china than in any other country. 64 the majority of these suicides have been women. 65 In the West there are three or four times as many suicides among men as women, but in China there are five or ten times as many among women as men. 66

This is a sad commentary on the lives of the wmen of China. While occasionally the suidide is caused desire for rewara or fane on the rart of a woman at the death of her husband or the young woman at the death of her fiance, 7 almost always it is because the burden of sorrow becomes too hard to bear and the only recourse is suidide. 68 requently desire for revenge is the wotive in suicide, or the chinese believe that the spirit of the deceased can avenge itself on the living.

63. King, Ecucational System of China, $\mathrm{F} .91$.

64. Ball, Things Chinese, p. 434, quoted in Dennis, Vol. I, r. 93 .

65. Capen, Soc. Prog. in Miss. Lands, p. 158. Dennis, Vol. I, p. 94.

66. Ross, he Changing Chinese, p. 198.

67. Headland, court Iife in hina, p. 280. Doolittle, soc. Iife of the Chinese, $p .78$.

6E. Dennis, Vol, II, f. 150. 
So sometimes when a woman has been cruelly mistreated, she comits suicide hecause she has no other vay of selfdefense.

$$
69
$$

When opiur ws so easily obtainable, it was very convenient for the one who ranted to comit suicide to take an overdose of rav opium. And when the opium crop was in there was an unusually large number of suicides?" The Chinese do not like to mutilete the body in death because of the belief that any mutilation will be carried to the other torld ${ }^{2}$ so other favorite methods are by eating matches, troken glass and broken jewelry, or by drowning.

Medical missionaries are very frequently called upon by the relatives of monen who have attempted suicide. cometimes these women re only feigning to attempt suicide in order to excite the pity of their tormentors, but more frequently they have in real earnest resorted to this tragic expedient. Often the physician, if called in time, is able to resuscitate them.

Christian missions teach the sacredness of human life and the sinfulness of self-murder. christianity also greatly ameliorates the condition of momen in China and removes many of the causes for suicide. The Christian Church defends the other ise defenseless woman and brings to her heretofore empty ife education and culture, respect and love. Hence suicide among Christian chinese Wonen is the very rare exception.

69. Capen, Soc. Prog. in Miss. Lands, p. 158. Ross, The Changing Chinese, p. 198.

70. Dennis, Vol. I, p. 94.

71. Ross, The Changing Chinese, pp. 149, 196.

72. Dennis, Vol.I,p.94. Vapen,Soc. Irog. in liss. Tands,p.158. 


\section{CHAPTER II.}

\section{EIUCATIONAL CONDITIONS}

yducational Conditions in the Past.

The school may be a very vital force in bringing about social progress, or it may be a powerful agency in retarding such rrogress. Jowhere do we see this fact so well il istrated as in the history of education in China in the past century.

Every one is fairly familiar with the old educational system of China. Let us look at it for a few moments from the point of view of its effect on social progress. First of all let us glance at the old examinations around which the system of education was built. Once every three years in every provincial cerital a three days examination was held. The few who passed this examination after further study went up to the national capital for another three days examination. The few who passed this examination were eligible for goverrment positions.

The Chinese established this system twelve centuries ago, Iong before our ancestors had thought of schools or had learned to read and write? They estab-

1. Out of nine or ten thousend who competed, only 250 or 300 could have the privilege of going to Feking for the examination. Out of this number only 6 could attein the high honor of being admitted a member of the Hanlim Imperial Academy. Reinsch, p. 439.

2. King, Educational System of China, p. 35. 
Iished it in the belief that the welfare of the state rested upon the education of its rulers. It is intersting to contemplate what right have been the result if they had taken the stand that education was desirable as a means of social progress.

But their system of education was not calculated to inspire progress. Their object in education was to le rn what confuoius had writ ien so as to adhere as closely s possible to the examples set in the good old times by the worthy ancients. The Chinese have a saying, "What Confucius teaches is true; what is contrary to his teaching is false; what he does not teach is unnecessary." Ihis was their creed. Vot mu h room was allowed in this system for progress. Confucius said, "The study of strange doctrines is injurious indeed." The man who suggested something new was condemned. The good man was the man who worshipped his thoestors and did as they had done. Fhe man who could comit to memory the ancient classics was the man who was given government office.

Although no provision was made in this system for social prosess, there were many precepts calculated to further a sort of static social welfare. There were a number of sayings of Confucius which if applied to existing conditions would have bettered the social life China. But unfortunately there was nothing in their 
educational system which encourased the students to apply their learning to existing conditions. In the examinations no questions relating to present day events were asked. A quotation from the classics tas given. The candidates must locate this quotation and must quote literally and extensively from the classics and elucidate the passages according to the standard comentator, Chu Hsi. Their quotations must exact, their penmanship flawless, and their coments must be those of the greater commentator. ${ }^{3}$ If any one had attempted an application of the priciples taught to existing conditions, his paper vould have been thrown out as unorthodox, and he would have lost his chence at a lucrative government position. All impulses toward original thought or practical applicstion of priciples were thus discouraged.

In the schools all over the lands the method of study was greatly influenced by this system of examinations. The little hoys were taught to commit the classics to memory. To effort at explanation was made. It is perhars unnecessary to say here that the language (Wen $1 i$ ) in which these classics were written was as unintelligible to these chinese boys s Iatin is to our chilaren. The little boy must catch the sound and the tones from the teacher and commit them to memory. As Dr. Arthur H. Smith said, all the mental furniture he

3. Lewis, The Educational Conquest of the Far Sast, p. 120. 
needed in this work was a "memory like a phonograph." The teachers of the classics all over the Empire ignored this precept of Confucius, "Learning, undigested by thought, is labor lost; thought, unassisted by learing, is peril ous."

Thus even the good things in the teachings of Confucius were largely without influence on practical life. Iurthemore, the conduct required of the pupil in school ha far more influence upon his life and his relation to the society about him than the knovleage he acquires. Although Confucius condemns bribery, his followers did not hesitate to resort to it as a means of advance. The fosition of Iiterary Jxaminer was a very lucrative one although his salary was meager. The average amount which the examiner was said to make in ran Chow to each visit, above his expenses, was fifty thousand dollars 5 This amount of course, came from bribes and presents which influenced both his abilit to see cheating and his jucigment as to the respective merits of the examination papers. After one had rassed the final exaraination at Peking, government positions were not ofen for every one. only after suit ible presents and bribes as the position forthcoming. Having entered upon his official career thus with soiled hands, and empty rurse, it naturally followed that instead of

4. "Gold is tested by fire, man by gold." Lewis, p. II4. 5. Iewis, Bducational Conquest of the rar Jast, p. 113 . 6 . Leroy-Beaulieu, The Awakening of the East, p. 206. 
following the mottoes with which he had crammed his memory, he continued in the course of bribery and aishonest dealing which this school system had encouraged.

The Educational System Reconstructed.

But here and there began to be f'eelings of dissatisfactio with the existing order. Tefore the Jaranese War, Irince Kung addressed a memorial to the trone advocating the introduction of some mathematical and scientific work into the educational system. Chang Chih Tung in "China's only. Hope" appealed for a change in the educational system in 1898. Other men who had the ear of the Emperor made similar appeals. The German and Russian governments had al so been instigating educational reform. Tissionaries had been opening schools throughout the smpire in which some of the vestern branches were taught.

In 1898 the Emperor, Kwang Hsu, astonished the world by heacing a nost wonderful eform rnovernent in education. He undertook to lift his country out of the hoary past into the vigorous present. The Emperor said: "We agree with the said sub-hancellor (who had memorialized the throne) and also that a simple knowledge of the classics is not enough to fit men nowadays for important fosts in the Imperial Government. That is most imxortant now is for men to have nowledge of the world, and of things going on outside of China. Such 
men are required for the Government, and eve y opportunity should be given such to bring to light their experience and knowledge." He further said that "We do not lack either men of intellect or brilliant talents, capane of learning and doing anything they ylease, but their novements have hitherto een hampered by old prejudices."

But the Emperor was slightly ahead of his time, and especially of certain memoers of his own royal family, and he was not strong enough to carry the scheme through. He was dethroned by the Impress Dowager and other reactionaries end all that he had done in the way of educational reform wat uprooted.8

Then came the Boxer uprising, after which the Empress Dowager was forced to flee to Hsi-an-fu. Cne of the any lessons which were brought home to her during that humiliating period was that Chira's educational system needed to be revised. On her eturn to leking she advocated the very refoms thich she had suppressed in 1898, but she took pains "to save her face" by making clear that her reforms were of quite a different nature from those previous ones. The Empress Do ager felt that the old system of education was at the bottorn of all China's dificulties. 9 she felt that the classical

7. Levis, Educational Conquest of the Jar Jast, p. 161.

E. King, aucational ystem of chine, f. 29. Fland and Tackhouse, China Under the Empress Dowager, p. 220.

9. Bland and. Backhouse, China Under the Impress Downger, p. 429. 
examinations were at fault. They were out of touch ifith modern Iife. Instead of these she decreed that essays should be ritten on subjects such as the following:

In Shantung.

state the advantages of constructing railways in Shantung.

state the important effect of the study of chemistry on griculture.

In Kiangsu.

As Chinese and Western laws differ and Western feople mill not sumit to Chinese punish ments, what ought to be cone so that China may be mistress in her om country like other intions?

A system of government schols teaching Jestern learning was established throughout China, with a university at the capital of each province, and auxiliary prefectural and district colleges and schools. The whole system was to culminate in an Imperial Univesity at Pekirig."

Lter she elt that ven this vas too small a change, and she decreed in 1905 at the instigation of Yuan Shi-k'ai that the old system of examinations should be abolished Ito ether and that graduation at one of

10. Richard, Contemp. 83:15.

11. Brown, The Chinese Revolution, p. 75. King, Erucational System of China, p. 30. 
new universities should be required instead as a frerequisite for official employment.

The old Chinese classics were to be taught in these schools along with the new learning, but the method of teaching them was to be changed. low the text was to be exxlained.'2 me new learning which was to be taught in these schools consisted in ethics, mathemetics, history (both (hinese and foreign), geography, biology, in the primary schools. The middle schools taught foreign languages, Anglish, German, Trench, Russian and Japanese, history, including chinese, Asiatic, European and American, geography, methematics, political science and political economy, hysics, chemistry, biology, Chinese classics and literature, drawing and physical drill. Practically the same studies were continued in the provincial colleges, With the acilion of oratory, law, military science and military drill, gymn.stics and geology and mining.13

There ras of couree, a dearth of teachers for these numerous new schools. ${ }^{14 / 5}$ From the first the government sent students abroad to surope and Anerica for preperation as teache:s. Many Jaranese came over as teachers and many Chinese went to Japan to get enough of the new learning to begin teaching in China. China herself lost no time in establishing normal schools. These were

12. King, Educational System of China, p. 52 .

13. King, Educational Evstem of China, Rp. 62-67.

14. The statistics of the Ninistry of gucation in 1910 gave 42,444 schools in China exclusive of mission and private schools, The number of stucents in these schools as 1,274,928. In 191 there was an increas $e$ of 10,206 schools nd 351 , 792 students. 18th cen. 72:619.

15. Erown, The chinese Revolution, $\mathrm{f}$. 77 . 
opened in the rrovincial caxitals and later in other centers. The province of Chinli by 1908 outside of Feking City, had 98 normal schools, havine 165 instructors, 3,448 sturients, 5,608 graduates, and also two normèl colleges with 46 instructors, 935 students, and 533 graduates. 16

th the present time these teachers as a body are incompetent. It would be impossible under the circumstances for them to he otherwise. The new learning was too foreign to their previous education. Their oprortunities for training in western methods were too measer. Here and there we find unusually good tieachers, rut these are the exception. Sometimes the pations were given to mere office holders instesd of to competent teachers because of rolitical influence. Hover, the equipment in these goverment schools is good. The govexnment hes furnished the money and they have been able to secure all the equipment that they knew how to get. We heer of a school in the extreme fest where the labortory was full of chemistry suplies from Japan which har been unopened. In equicment, government schools excels that in mission schools.

Their discipline is extremely bad. The young students are drunk with the ir sense of new freedom. 18

16. King, Educational System of China, p. 75.

1\%. Brom, The Chinese Revolutior, f. rir.

18. Smith, 19th Cen. 72:6il. Erown, Chinese Pev., p. 77. 
Realizing the incompetence of their teachers and no Ionger required to reverence them as pupils were taught to do in the past, they feel that all authority is in their hands. In one place we hear of their going on a strike because the faculty would not dismiss a certain teacher. In another glace we hear of their demanding that the teacher give them easier exmination questions or lower the passing grade. 19 Again ve hear of pupils cemandiog that the exanination be postioned hecause they were not krepared. In another place we hear of pupils gublicly insulting their teacher because he had given them lower grades than they wanted. In Shangung every government school went on a strike at some time during the two years 1910-11?

It is a feriod of reconstruction. Te cennot but believe that eventually chine will come out successfully. It is no small uniertaking to step from the Phirteenth Century into the Trentieth in a decade of two.

Influence of $\mathrm{I}$ issions in This Reconstruction.

Ifisionaries and mission achools have had no small part in this work of reconstruction. "ine efficient educational work done in these schools has been a great oject lesson and a great factor in hastening the new educetion in China." 21

The Chinese covernment hes secured presidents

19. Smith, 10th Cen. 72:6\%1.

20. Smith, 1oth cen. 72:621.

21. King, Educational System., $\mathrm{e} .8$. 
for several of its universities from among the missionaries. Ir. A. P. Martin, who had for 25 years been president of the Imperial Feking University when it was inaugurated in $1990 \mathrm{by}$ the Emperor: ${ }^{2}$ After the Doxer trouble he became president of the University of Hupeh and Hunan. $^{23}$ Ir. C. D. Tenney was presiclent of the Tientsin University up to the Boxer outbreak, and is now suxe intendent of Education in Chinli Frovince. As Superintendent of Education he crganized middle schools throughout the rrovince as feeders to the University. By the spring of 1904 he had 14 such schools organized with an average of about 50 students in each $\mathrm{school}$. The teachers of these shols vere former students of Tientsin University, who entered into the work with ruch enthusiasm and considerable success.4 Dr. John C. Ferguson, who founded. Tanking University (Nethodist), vas resident of the Goverment Janyang Cllege in Shanghai until 1902. After the Boxer trouble Yuan Shi-k'ai, Viceroy of the Itorthern provinces, selected Ir. W. M. Hayes as Iresident of the new Frovinoial college in shantung. At the request of Yuan shi-k'ai, Dr. Hayes organized the school province in Shantung Frovince. Yuan Shi-k'ai recognized that this wes the work of an educetor of no mean ability, and he presented a copy of it to the Empress Dowaser, who thereupon

22. Lewis, Bau. Com., r. IYe.

23. Martin, Awakening of ., p. $26 \%$

24. King, Educational Jstem of China, $x .41$. 
decreed that this system should be followed in all the provinces and sent copies of it to all the Viceroys. In the province of Shansi, after more than a hundred missionaries had be en mas sacred during the Boxer uprising, the government asked Tr. Timothy Richard what was the best vay of solving the trouble with the foreign powers, and after consulting with various other missionaries in Shansi he proposed that the government should, in lieu of indeminty, fay annually for ten years the sum of 50,000 taels toward the founding of a university for Shansi Frovince which would by its teachings end the ignorance which had been the principal cause of the massacre. The goverment placed the aministration of the university and its funds in the hanos of Ir. Richerd. Wen Ir. Richard came to Tai-yuen-fu in lo02, it s found hest to unite with a frovincial college already sarted there. The college already started wes to become the chine e department of the University and the schol founded by Ir. Richard was to teach the wstern branches. This school hes a good foreign faculty, is well attended, and his done excellent rork. 25

Missionaries vere also of service to Chine in the formetion of the Indernity school in feking. Tsing Hua College. It is in this school that all the young men are trained who are sent to America by the Chinese Government on the Indemnity Fund. These students come fror all 25. Richard, Con. Fev . 85:11. Kine, isdu. Sys., 73-74 
the eighteen provinces and are a splendid rody of icked. young men.' $\mathbf{2 6}$ ihere are at the present time nore than 700 of these students studying in America. They will be the leading officials in Iew China. This school has on its faculty fifteen American Christian froferoors who were selected for the govemment by Mr. Fletcher Brockman of the chinese Y. I. C. A.27

Eut mission work nas. furnished not only for ign teachers for new Chinese schools but also many able chinese teachers. The government schools recognize that the best teachers come from the mission shods, and are eager to secure them. The president of the Feking Indemity School is d Christian, educated in a mission school. Nir. Chang Po-ling, Irincipal of the School in Tientsin founded by the Imperiol inister of gacation, Ir. Yen, as a model ochool for all china, is ar active Christian. 28 "Teng Chow College furrished 13 Chinese professors, all Christians, for the Imperial colleges in Peking, Ianking ani Shanghai in 1898. St. John's College provided Ianyang College with three. The Wu chiang Christian High School has given up its choicest instructor to recome the headmaster of a government school in Hureh, and in like menner grovineial and locel authorities are seeking the services of hundreds of young men trained in.

26. Brown, Chinese Rev., x. 77.

27. \$ddy, W. W. 28:411

28. It is interesting to note in this comection that Prof. Robert $\mathbb{N}$ CElroy, head of the lepartment of History and lolitics at Irinceton University, leaves liay 20, 1916, to take up his duties as Bxchenge Irofessor at ring Hwa College. 
Christian colleges.. 29

The majority of the textbocks wich these new schools use had been translated and xrepared by the mission body. Ir. Timothy Richerd said that a quarter of a million dollars worth of text boks vere sol d in shanghai in 1902.38 Ceograrhy and history texts had first heen trenslated. Tathematics and fhysics soon followed. Z0010y, mechanics, hydrostatics, electicity, mineralogy, light and heat, and many others came next." At the present time the Society for the Diffusion of Useful Knovledge has the task of provicing text books. 32

Fresent Work of Iission Schools.

The work done in the mission schools is superior to the work done ${ }_{10}^{\text {enoverment }}$ schools. 33 Dr. King, Vice Fresident of Feking University (government), speaks of the "excellent educational work one in the mission schools and universities-a work that has $u$ to date been the most efficient of all educational work done in the Impire." 34 . A. Ross, whose travels throughout china gave him the opportunity f orserving a large number of schools, said, "At this crisis the doren-dd mission colleges planted throughout the Empire, mainly by

29. Iewis, Edu. Con., pp. 206-7.

30. Erown, Chinese Revolution, p. 75.

31. I ewis, Edu. Con., p. 196.

32. Iartin, Awakening of China, p. 287.

3. rown, Chinese Revolution, p. 85.

34. King, Hau. Sys., p. E. 
Americans, have the opportunity to render a great and statesmanlike service. In or ganization, management, staff, curriculum and discirline, the best of them are far surerior to the government colleges, In their work they aply a scientific fedsogy of wich the chinese know nothing. They impart western ideals of bodily development, clean living, individuality ana efficiency. ${ }^{35}$ The Chinese recognize the fact that their children have better educational avvantages in the mission schools and are willing to pay a comparatively high fee to get their boys into these schools, rather than to send them to the government schools, which are free..$^{36}$ "H. I. Chang Chih-tung (author of "China's Only Hope") "anted to send his oldest grandson to Boone University in Wuchang, and

35. Doss, C anging Chinese, f. 343.

36. Broornhall, Chinese Emp. II7.

37. This suggests the question of the advisability of compulsory attendance of religious services in mission scho Is. While it is not properly within the scope of this thesis to discuss this question, perhars I will be prdoned for referring to it here, since it has been so often discussed in cornection with the work of mission schools. It is the custom generally in mission schools in China to make attendance upon religious schools compulsory. Fersonally I think that it is better not to make it compulsory. Attendance of the Bible classes in the curriculum may well he compulsory recause the rission schools ere established $7 y$ the hurch first of all to teach the Bible and until the students study Christianity they do not know whether they want to accert or refuse it. But attendance upon church services should not be compulsory because compulsory religion is the same as no religion, and hecause those who ettend voluntaryily do so in a more worsiciful spirit and will more probably continue to attend church services after leaving school. In a school of which I was principal in China, we made attendance of church eervices voluntary and found that there was no decrease of attendance but a bet er spirit generally in regard to christian worsip. 
Give a considerable annual contribution on the conaition thatpis granison should be excused from attending church services.37 This request was refused by the authorities and he sent his grandson to Jakan. Iater, however, he changed his attitude and sent his nerhew to toone." 38

Course of tudy in lission Schools.

The Chinese classics are taught in mission schools. The history and life of China have been so much influenced by these classics that the education of a Chinese young man would be quite incomplete without them. Chinese penmenship and essay writing are of course, also taught. Unfortunately it is difficult to secure hinese classical scholars who are fitted to teach these subjects according to modern methods. Herein lies perhas the weakest point in mission schools. The students recognize the comparative incometence of their teachers of chinese classics and neglect the study of these subjects. The missions recognize this defect and are trying to instill some pedagogical principles into the classic teache"s' heac. But, to use a homely proverb: "It is hard to teach an old dog new tricks." This is esfecially true if the dog is a fossil.

The fible is taught in mission schools. Iteedless to day, little that is denominational enters into this teaching as a rule. There are so many things about the Bible which the Chinese co not discuss the comparatively unimortant denominational differences. The Fible is taught both as a book of religion and as book of rorals 38 Natinne 1 Review (Cnine) Jan.29. 1916 
and has proven to be a most powerful agency in the transformation of the social Iife of the student body. English is taught in all mission prammar and high schols in China. There ws some onjection to this subject in the beginning, but now it is generally conceded to have a rightful place in the curriculum. The Cinese, as a rule, are very eager to learn English hecause they ch obtain better positions if they can speak the english language. Furthermore, the teaching of English is desirable because there are so many good things written in the english language which are not yet translated into Chinese, and a nowledge of unglish opens up a veritable treasure house to the sturient. The study of science has proven very beneficial in promoting accuracy and a sense of the value of truth among the stucients. The Chinese are proverbielly inaccurate and untruthful in their staterients.

In adaition to the above subjects, the subjects which are regularly taught in our grammar and high schools in America are taught in the mission grammar and high schools, with the one exception that Japanese and Chinese history are given more prominence in their curriculum tha in ours.

As one con readily see, when one considers the difficulties which the Chinese language presents, one of the chief troubles is the overcrowding of the curriculum. Whe result is that the pupil has lit tle time for the 
preparation of his Jesson. To solution of this difficulty has thus far been diecovered. Some efforts are being made toward the simplification of the Chine e written language. If that can be dore, it will be a great step $t$ ward the popularization of education in Chine. ${ }^{29}$.

Tanual Training.

Ianual an industrial training are seen in a few of the mission schols. The attitude of the chinese toward marual labor of any kind makes the introduction of this work into the schools for chinese doubly imperative. one of the reasons for its introduction into Anerican schools is the changing industrial stituetion in America which has taken from the home so large a part of the manual work formerly done by the chilaren. How much more necessary is it to have manual training in china where manual work of any kind has not only been out of the hands of the student class, but has been considered as quite bereath their dignity.

Dewey, in "ihe School and Society," in discussing the introduction of manual training into schools in America, says, "The school itself shall be made a genuine form of active community life, instead of a face set apart to learn lessons." He speaks of the need of common anc productive activity, division of labor, selection of

39. Vational Review (China), Jan. E, 1916. 
leaders and followers, mutul co-creration and ermlation. He derlores the lack of the motive and cement of social organization and the want of social sirit in the ordinary school roon. It is a school crime to help each other. "The mere absorction of facts and truths is so exclusively i dividual an af fair that it tends very naturally to pass into selfishness." Then he speaks of the change wich comes with the introduction of manual training-the change in the social attitude of the students and the change "from a more or less passive and inert receptivity and restraint to one of buojant outgoing energy. "40 An extremely interesting exeriment has beon tried by the Fing tu. Christian institute." Here industrial training was introduced. Practical trades we e taught. This department developed into a self-supporting dexartment, and the students were faid $2 \frac{1}{2}$ cents per hour for their work. lany foor students who har heen previously supported by mission funds, became in this way self-supforting. The students we allowed to have this manual training no rore than two hours a day except saturdays. This departure received the unanimous and enthusiastic support of the Christian Chinese. The school had so many applicants for entrance that in 1913 the entrance requirements were raised one year and only those wo seemed in greatest reed ere allowed to enter. The

40. Dewey, "The School and Society," p. 2\%. 41. Literary Digest, 40:1050. 
effect on the school was marked. The literary ork was better than before. There was seen a new respect for manual labor and a new joy in it. A new self respect was felt by the students who had become self supporting. In reference to this last improvement, the rincipal of the school said, "Henceforth we do not furnish a cash for board to any student."

However, where industrial work has been introduced in the Christian schools, one common mistake is that this industrial work only helps them in self supfort while they are in school, and does not help them to become an urlifting force in the industrial development of china. The things made in the industrial departments of mission schools are such as pander to the luxurious tastes of foreigners: rugs, nats, curtains, lace, embroidery, drawn thread work, osier basket work, etc. mile these trades are of enefit in helping the young people tow ras selfsuprort, they do not helf solve the big industrial problems of China. There should be more scientific egriculture, foultry farmins, forestry, and horticulture.

Mission schools vould do a great service to Chinese reople if they could elp tiem to pass through the period of storm and stres which the change in industrial conditions will surely bring in. Pishop Bashford speaks of the signs of industrial awakening which he sees in all the ten provinces which he visits $4^{2}$. A. Ross in 42. Iiss. Review 19:352. 
1911 wrote of the number of industries that had spring up within the last 20 years: Forty-six silk filatures, more than a dozen cotton spiminemills, two woolen. mills, factories in shangha for making glass, cigarettes, yellow bar soap, tooth brusties and roller-process flour, and the great Hanyang iron and steel works." 3 In the outlook we see accounts of the electric lighting installations in ohangsha, Hangchov and Foochow, a brick factory in Canton with up-to-iate British machinery, capable of turnine out 40, 00 bricks a day, a cement plant in Tongshan, with a capacity of 500,000 barrels a vear, flour mills in Chungking and Yunanfu, a leather factory and tannery in Canton, a match fectory in Hangchow, paper mills in Hankow, a large printing establishment and a rice culling riill in Changsha. *4

That young Chinese statesman, C. T. Weng, sees the coming change and also the cossibility of material helf which may be rendered at this yeriod by the mission schools. There are certain manufactures entering into the acute strugglee between well organized labor and equally well organized caxital in the vest, but I believe I am right when I say that these strugeles would have been less acute if not altoether avoided had the sirit of love and brotherhood as taught in the Christian faith perreated both labor and carital. In China industrial

43. Poss, changing thinese, p. 118 .

44. Outlook, 102: 700 .

45. The Chinese Pecorder, liarch, 1914. quoted in Iit. Digest, liay z, 1914. 
development has not advanced to that stage when the interests f labor anà capital clash. Nould it not be a splendia thing if the church in china could inculcate a new spirit in the development of industry by inaugurating cuch a policy of industrial education in the mission schools that great captains of labor and leaders of industry would acknowledge the fact that they are but stewards of Gor's talents on eerth?:

Normal Schools.

Some normal schools have bo n established by missionaries, but too little emrhasis is fleed on this phase of the work. The recently reconstructed educational systom of China cils for nearly a million teachers. The Government has established great normal schools in many cities, some having 1000 teachers in training. 46 Up to the present time teachers trained in these normal schools have not been the equals of those trained in the Christian schools. Furthermore, these schools have not been a le to supply teachers in sufficient numers to meet the need. Herein lies an unprecented opportunity for Christian missions in China. A great normol chool should be established in each province. This is the ne ed of the hour. A great service would be rendered China if in this formative period bood normal schools could be furnished her as models for her own, and well

46. تddy, W. W. 2e:409. 
trained miscion schol teachers could co-oxerate with the Government trained ones. In supklying to the fovernment schools their best teachers, Christian Missions could dominate the intellectual life of china with a distinctively christian influence. 47

Other Tethods of Educeting the Iulic.

Besides the school, several other methoas of educating the Chinese people have reen found most effective. Books and magaines have had great influence. Hewspapes are doing great service. Formerly there vas only one newspaper in China. This was published by the Government at Feking. In 1912 there were more than $200 \mathrm{C}$ inese newspaps. ${ }^{8}$ The reasons for this change are various. Christian missions had a share in ringing it about. Y.J. Allen gave a life time to this cause. In every center there was a paper printed by the mission workers. These papers created a desire for information in regard to cublic events. Another means of educstion is the curlic lecture. The Y.P. A. has used this method more than any other organizetion. Prof. Rohertson, of the Y.I.C.A., gives ell of his time to the giving of illustrated popular lectures on scientific subjects such as the gyroscope, wireless telegrarhy, the aeroplane, etc. The public lecture was a mighty force in the anti-oxium and the anti-foot-bining crusades.

47. Miss. Rev. of the World, 22:68:.

48. Brown, The Chinese Revolution, $F .74$. 
EDUCATIOIT OF UOMAN

With some fev excertions, the chinese have held since time immemorial that the educetion of their daughters was an altogether unprofitable and imossible undertaking. consequently il it eracy anong women has been almost universal. The late imress Dowager and the mother of Yuan Shi-kai have been brilliant exceptions to this rule. 49 here are ther such excertions recorded in history and exalted in yoetry, but they are more rare than are presidents' wives in the united ctates history.

The chinese have really believed that women had no minds and were therefore incarable of learning to read. The mas es still are of this opinion. hile in China I knew a number of women of the poorer classes who had been so often told that they had no minds that they themselves had come to be conviriced of the truth of that statement. Furthermore the chinese fether hed no inclination to 80 to the exfense of educating a girl who was at an early age to be lost into her husband's family.

Accordingly when thristian missionaries first essayed to open schools for girls, they met with little encouragement from the Chinese, to state the situation mildy. In adiition to the above objections all sorts of superstitions had to be dealt with, one of the rost 49. Bone, Ind. 75:667. 
prevalent being that the miseionary manted to take out the eyes of the Chinese girls to make medicine out of them. The littie girls had to te paid to come to school, sometines by furnishing them food end clothing, and sometimes by atually giving them the small sum of ten osin a day.

The first of these schools for girls in China was opened by Miss AIdersey in Minglo in $1844 .^{50}$ The next year she had 15 gupils, and by 185: she had 40. Other missionaries soon followed her example, and a number of schooz for girls were established in different centers throughout China in spite of great op rooition on the pert of - hinese.

The class of students who first came were poor. Only poor parents would allow their girls to come, and these sent them hecase of the slight financial aid they received. $5 \%$ Foundlings were secured for pupils in some schools. When ahout 1970 education for girls began to gain in popularity and the numbers in attendance at the Christian schools increased, missionaries began to feel th t possibly they might withdrav the financial inducement, a noessary evil hich they had ways regretted. In the Fresbuterian school in ing o, lolothing was no longer furinshed. In the Baptist school in the same city, parents tere required to gay something toward the support of their daughters. Industrial departments rere added 
in other schools to encourace self supjort. 52

$$
\text { By this tine it had begun to dawn on a few of }
$$

the Chinese parents that their daughters f receiving an education. They also found that the educated daughters mere even nore dutiful in the home, and that they could be married of quite as advantageously as their uneduceted sisters.

Then the higher classes began to feel the need of erucation for their daughters. Mr. Young J. Allen, the venerable stetesmanlike misionry of shanghai, felt that the time fres ripe for the establishment of a school for the upper class Chinese girls. So McTyeire School, of Shanghai, had its origin. A few othur schools of like character were established elsewhere.

Py this time many young men were heing educated according to Western methods abroad or in the mission schools in China. These young men knew the advantages of eduction for roune women, and demanded that their parents engege them to educated young women. Those who had Iready been engaged demanded that the firls to whorn they found themselves engaged be sent to one of the mission schools for education. Sometimes the young men's family bore the excenses for the young woman's education. This demand for educated wives was the sure token of populerity for schools for girls.

After half a century of missionary effort towards 5\%. Burton, Dacstion of foman in China, p. 56. 
the cause of woman's eduction, in 1897 the first purely native effort was made by a society of officials and merchants in Shanghai, who opened a girls' school in that city with 16 puxils. 54 The matron and one of the two teachers of this school were Christians. 55 This school was closed in less than two years by the impress powayer, but other schools of a similar nature were opened by Chinese in the treaty ports. The Emoress Dowager learned many lessons through her humiliating experiences following the Boxer uprising in 1900. She came back to the throne a new woman, determined that her ancient country should march to Iwentieth Century tine. Among other reforms she advocated. the education of China's wornen. In 1906, she sent a comission abroad to investigate and make regulations for the establishment of girls' primary and normal schools. Schools for girls, both Government and private, sprang up rapidly. It was inpossible to provide enough competent teachers. Then normal schools sprang up/in china with the avowed curpose of training teachers quickly. Fut such haste produced incorpetent teachers.

Mission schools now have wonderful opportunity for training teachers for these numerous covernment and nivate schools wich have been recently established. If the christian schools can furnish Christian teachers for these goverment and private schools, they will have 53. Voung men being educatod in merica so etimes write back asking that exrression or music be added to the young woman's accomplishments. Musical missionaries sometimes have had hard work trying to create musical tralent in certain fastidious young ren s future wives, where no talent existed originally.

54. Edin. Rev. 216. 55. Eurton, r. 107. 
a wonderful opportunity for influencing the romanhood of hina. Government and rivate schools recognize the superiority of the mission trained teachers, and are glad to secure them. But all mission schools for girls need more child study in their curriculum. A few kindergarten training schools are doing good work. The standard of these should be constantly raised and the number increased. Put it is a fact that the rajority of missionaries going out to the field ne to knom more about how to train teachers. Missionaries who come home on furloughs need to take teacher training courses in up-to-date teachers' colleges while in the home land. Every school for girls in China should give courses in child study and in the theory and practice of teaching, not only for the sake of the young women whe will teach school, but also for the sake of every chinese girl who "ill become a mother. 56

Irission Schools for firls have produced wives and mothers far superior to any that China had known. These women have become intelligent help-meets and sympathetic companions for their husbands and faithful

56. Here and there we see beginnings of this study, as in West Scochow in Davisison Girls' School, which hes the advantage of being situatea on the rame compound with a kindergarten training school, the faculty of which co-operate ith the faculty of the firls! school. Ginling Collere, the only college for women in the great Yangtse Valley, which was opened in 1015, has sorne courses in teacher training and hopes to have a normal derartment in the near future. 
mothers to their chilcren. But more might be accomplished if more emphasis were placed on definite training for home making. Some mission schools have the beginnings of home economics, but they need far more than the have had. We in America are coning to recognize the valle of home econonics for our girls in the grades and high school. There is far greater need for it in Chi ga $_{\wedge}$, where conditions are so unsanitary, where disease lurks in every corner, and where the office of home maker has not received due respect. Mission schools need courses in home economics which are suited to Chinese conditions, Study should be made of chinese foods and food values, of Chinese homes and their sanitation and cecoration, of Chinese textiles and clothing, of the dangers of unsanitary conditions in China, of the means of reducing the high infant mortality in China, etc.

Unfortunately there is something fundamertally wrong in the attitude of some lady missionaries toward the home life. They undervalue the home life as voman's vocation. If a Chinese pirl is sturid they say, "This girl is not very bright, let her get married. This one is bright, we want her to teach." They are too short sighted to see that if this rule were followed generally, the second generation of Christians would all be stupid. 
Iission workers should seek to elevate the home ideals and practices of not only the girls in the girls' schools but also of the grown women with whom they come in contact. Public lectures and exhibits are beneficial. Classes in things pertaining to better home making might well be taught. Commencent exercises and entertainments given by the girls' schools could very well be utilized for educating the outside women. Formerly these entertainments were necessary as a means of advertisement for girls' schools and woman's education. But this is no longer necessary. Now entertainments might be used as a means of enlightenment to the outsiders. The princigles of home economics and child training learned in the school could well be shown in pageant or play or rantomime. 
CHAPTER III.

\section{SANITATION AITD HYGIENS}

The Chinese physicians have in the past had no scientific knowledge of the treatment of disease or the care of the sick. They have been absolutely unable to guide the people into ways of health because of their own profound ignorance. Their remedies have consisted in such things as the skull, teeth and toes of a tiger ground up, dried snake skin, ground to powder, and the Iike. A headache they think is caused by the entrance into the head, of an evil spirit, and think they rust break the skin in order to allow this syirit to escape. Surgery is unheard of, as the use of the knife has been practically forbidaen?

Because of their ignorance of the dangers of contagion, exidemics of smallpox, diphtheria, typhus, cholera and plague sweep orer the land, kiling hundreds and thousands of reople. Iittle children, with faces covered with smallpox eruptions, have come to the sunday School on Sunday afternoons, and have been much offended because vre made them go home. One day I was pursued by a whole family of beggars, all of whom apparently had smallpox. It is inpossible to keep away from smallyox in china. The bubonic plague, which in the nineties took

1. Douglas, society in china, p. 156.

2. One missionary's farily in America wrote her to be sure to go to the other side of the street if she saw a case of smallyox. But the streets of soochow are only 8 feet wide. 
millions of lives in India, and has not yet een wholly suppressed, came from china. Tuberculosis is very prevalent in China because the people live in dark, damp, unventilated, overcrowded houses, and take no precautions against infection. Leprosy is found, especially in the South: Malaria, dysentery and sprue abound. The Chinese do not understand the necessity of clean food. The things one sees on the streets are enough to make one never want to think of eating again. Fruit is cut open and placed on a little table, right on the indescribably filthy street. Other food is cooked near by and exposed to the air and the flies, waiting for a buyer. one wonders how so many chinese have ever managed to survive so long.

The tahle manners are calculated to spread disease. Every man dips the chop stick which he has been using into the cormon bowl. It he is polite, he gives his neighbor a generous helping with those same chop sticks. Such diseases as pyorrhoen and syphilis of the mouth spread raxidiy under such conditions. After the meal, a towel dipped in ram water is passed around the tanle in lieu of napkins. As it is used by every one at the table, there is here a new opportunity to get any germs which one has escaped before. Similar tomels are passed around on trains, especially in hot weather. 3. Iit. Iis., 45:510. 
After being used, they are placed again into the basin of warm water, where gerns have a favorable rlace to multiply before the towels are used again.

Medical missionaries came to China early in the history of Protestant missions. Ir. Peter Parker, coming in 1834, was the first of these." The need of scientific medicine was so great, and the physician was so valuable a worker in overcoming prejudice and creating a friendly feeling toward Christian missions that with alnost every chapel sore form of testern medicsl work ws introduced. At the present time there are in china 300 rotestant missionary physicians, 5000 Western-trained Chinese physicians, and $250 \mathrm{mission} \mathrm{hospitals,} \mathrm{treating} \mathrm{more} \mathrm{than}$ $2,000,000$ patients a year..$^{5}$

rhese physicins have done an invaluable service to China in relieving and preventing suffering and disease, and in revolutionizing the nation's ideas of the treatment of the sick.6 A notable case is the assistance which they rendered in the stamping out of the pneumonic lague in lorth Chine in 1912. In accomplishing this the missionary physicians worked together with the chinese Government and with Cinese physicians trained in modern methods. This plague orisinated in Siberia where Manchurians went to hunt the mamot. They acquired the

4. Martin, Awakening of China, p. 284.

5. Iartin, Awakening of China, Review of Reviems, 224.

6 . Ind. 55:1849. 
disease from this animal and thereupon scattered to their hones, taking with them the deadly disease. The disease made racid headway in lanchuria. The total num er of deaths there $¥$ s estimated at 65,000 . Whe disease threatened all of the neighboring countries, China, Russia and all of Europe. In Harbin, in an old-fashioned Chinese hospital, there were 1600 plague patients. The only recourse of the chinese physicians vas to acupuncture, which failed absolutely and every one of the 1600 patients died. Thereupon the chinese physician in charge threw up his hands in despair, saying he could do nothing, and asking for foreign help. The Prince favored the Progressive party, and appointed Dr. Uu Iin-teh to take chree. The missionaries accepted his readership, and, together with a number of rnission and foreign trained Chinese physicians, served heroically unaer him. Five of these phoicians lost their lives in this cause. Put the thoroughness and promptness with which this body of physicians acted in disinfecting houses where the plague had been and in burning the bodies of the dead, resulted in the complete stamping out of this terrible plague. Formerly the medical missionary stood alone. Now he is in very grood repute, and has many native helpers of the highest order. The chinese physicians thom he has trained are recognized as capanle and efficient in their profession, not only by their foreign colleagues but by their own Goverment.' A national fiedicsl

7. The Gowernment is now laming the erection of a great modern hospital, to we a model for the mole country. lational Review (China), Feb. 5, '16, p. 96. 
Association has been formed, and is publishing as its organ "The liational Ifedical Journal of Cina." The editor of this journal is the Chinese chysician mentioned above who ws president of the anchurian Ilague Irevention Conference. Ihis journal "contains highly technical articles and original research and observational work by men equal to the hest of their fellows in the rest; and it is in both Jnglish and Chinese, a fact which to those who are inf cosition to know what it means, speaks volumes--literall y." 8

In China the woman doctor has stepped into her place almost from the very first. Very frequently it has been impossible for chinese women to be treated by men doctors, and the need for the woman doctor mas arparent from the beginning. Some splendid Chinese women doctors have been trained in china and America under the suspices of Christian missions. Foremost among these are Ir. Mary Stone and Ir. Ida Kahn, of Kiukiang.

Nedical missionaries in China are now torking in conection with the China liedical Board of the Rockefellex Foundation. This board plans to esteblish orly one or two medical schools in China, although it is vell backed financiall $\mathrm{y}^{9}$ in order to give the chinese eple a model showing how this work should be done. Experts are sent from America to these schools, and every medical

9. One of these schods is a union of mission medical schools and the rervard ledical Gcool in Ianking. 8. Jational Review (China), Feb. 5, 16, p. 96. 
practitioner on foreign pay within a chosen area is supposed to spend three months every year at the central medical school. Tesides this medical school work in china, the Rockefeller foundation offers six fellowships of I000,00 gold each, and traveling expenses, to promising Chinese physicians for study abroad. Five nurses" Scholarships for study in America are also offered. Imphasis is laid by this board uron the need of more intensive work $f$ a higher grade.

Education of the general public as to sanitation and hygiene and the precautions necessary to prevent the spread of disease is undertaken by the medical missionaries. Iublic illustrated lectures are mede use of to this end. Mission schools spread useful information. Iife in their schools is made as wholesore as possible. Some schools are trying to improve the table manners of the Chinese. Two pairs of chop sticks are provided for each person, one for one's own use and other for use in the cormon dishes. These extra chop sticks the students have dubbed "health chop sticks." This custori shovld be adopted in every school.

In Changsha a "Women's Social Service Ieague" was organized in connection with the hospital work there in the auturn of 1913 . This league did valuable service in the way of educating the poor in ways of self protection against disease, gave lectures on tuberculosis, gave out circulars on contagious diseases, care of the 
teeth, trachoma and other eye diseases, and the care of babies. It also conducted a campaign against infant mortality, secured grounds for gublic gay grounds, and opened milk stations for the free dispensing of pure milk. 10

The large arrount of sickness and disease and the high mortelity rate have been a great burden to the Chinese people, and have been one of the great hindrances to the development of a nigher grade of scial Ife in china. But the reaction of the death rate will no doubt overcrowd China still more than at present. The high birth rate, which is aue to ancestor worshix and early marriages, will not be so easily reduced as the death rate. Not until it is reduced can the chinese standard of living be materially raised.

10. Hume, Survey, 34:575-7. 
CHA.TTER IV .

\section{INDUSTRIAI. CONDITIOIS}

The Ioverty-Stricken Condition of China.

China is the land of beggars. It is not known how many beggars there are in China. on one day--a festival day, when there was an unusually large number of begars on the streets--I counted betwen 50 and 60 on two locks of one street. Dut even on ordinary occasions begers seem to be everywhere. They gather especially at the gates of temples or plessure gardens where throngs of people come and go.

There are all kinds of beggars: religious beggars (Eudahist), who are taking a course in self-denial to acquire contempt for things of earth, or are enduring sorne kind of physical self-torture to excite sympatiny for some religious cause; blind beggars, some traveling singly and some in trings, led by a child or some rough fellow; deaf and umb beggars; begrars with deformities, wounds and sores, some real and some make-relieve; surly, coarse heggars, not dexending on deformities to excite pity, but uron their overbering s irit to inspire fear; snake cherming eggrs, who bring out their snakes to intimiaste the reluctant almsgiver; iron ball eating beggars: knife eating beggars; beggars who balance things on their noes; beggars who throw iron projectiles; 
beggars with trained dogs or monkeys; beggars of all ages, grandparents, parents and little children.

eggars re an organized class in Chinese cities. The city of soochow is divided into districts and has 24 beggar heat men. Each head man controls the beggars in his district, assigns to the local beggars the district where each may beg, collects from the stores the beggar immunity tax of from 100 to 1000 cash per month, keeps the stores which here paid this tax free from beggars, colleats "similar tax from families cele rating marriages, betrothals, funerals, etc., and protects them also from begars! The head man receives no salary, but makes all he can get excet what he is compelled to give to the traveling beggins who come through the city. 2

where are rany, many people in China who are barely above the beggar class. The vages received by the laboring classes are so small that the standard of Iiving is deciaedy low, and they are often pushed below the poverty Ine by the force of circumstances. The rases of a coolie are from 5 to 6 Mexican a nonth. romen make exquite emoroidery for from $\$ 3$ to 6 liexican a montr. 3 . A. Ross, after investigating the wages given in various parts of china, makes the statement that "in any part of the Impire, willing laborers of fair intelligence ay be had in any number, at from

1. To each store which pays the tax he gives a printed slip of paper signifying that the tax has been paid. This slip is pasted up on the wall in a conspicuous place.

2. Gee, A Class of Social out casts. 
eight to fifteen cents a day." ${ }^{3}$ on tilis small sum the laborer supports hinself, his wife and is children, of whom there is usually a large number.

As one walks through the streets or along the country paths, one is impressed y the poverty of the Chinese. rhe tiny shors, the small divisions of food on the stands, ceanuts and chestnuts divided into piles of three, oranges divided into sections for sele, the small houses, the garden plots which are the rice fields of the fomers, all bear witnes to the extrome poverty of China.

Causes of Poverty.

And yet the poverty of China is not due to lack of industry. hs you walk thr ugh the country you do not see a single we d in the rice fields. You see men, women and children out working early and late. As you walk through the streets you see throgh nxen doors the weaver busily throwing her shuttle, the jade cutter whirling his wheel, the embroiderer plying her needle, the sowyer sawing the big logs, the wood aarver cerving fine wod, and the spinner spinning her thread.

One of the reasons for the roverty of China is the overor wing of population. The desire for rale progeny to carry on ancestor worship is so great thet sons are marri a at an early age, so etinos concubines are brougt into the famly, and children are brought into 
the world without regerd to the amount of rice ther is for them to eat after they arrive.

But the reso rees of china have not been exhausted. A sreat part of china's resources have not been developed. China has vast mineral wealth lying almost untouched. Jaron Von Pichthofen, the expert Geman geologist, states that the coal deposits in Shansi are the nost etencive in existence? covering many thousand of squere miles and containing sufficient fuel to surply the world with ell the coal it needs for one thousand years. Coal fields abound in Chinli, Shantung, Honan. Funan, and Yuman. Much of this cool is a good quality of anthracity. Iron ore is found pofusely in Honan, and is also found in several ylaces far removed, which leads one to the conclusion that there is wide distribution of iron deposits. Gold is found in many provinces. Iead, tin, zinc, copger, sulphur, mineral oil and mercury are found in different sections of unina. Eut the mioes are undeveloped and the railroads necessary for transportation of this mineral wealth are not built. The chinese have been afraia of distrubing the dragon if they dug into the exth. Iesides, the Chinese have well grounded suspicion of each other, and so are afraid to invest cepital in enterrises controlled by chinese. They fear that the caxital will all disaxpear hefore any returns core in.

4. Ferdinand Von Richthofen: China, Erge"nisse eivener Reisen und darauf gegrundeter studien, quoted in. Colquhoun, p. 6I. Sddy, W. 4ly, and Krausse, x.2l. 
The custorn of "squeezing," or of taking surrefitious comissions on all money that gasses through one's hands, runs through a.lI phases of the chinese busness worla. The house cook in meking gurchases for his master takes a certain amount of the money he scends as his commission. He regards it as his right. If you dismiss hin you will get another just as bad who will probably divide his commission with his predecessor. But if you so out to buy provisions for yourself, you comot secure them as cheaply as your cook coula even with his comission. So you subrit, linless you can make a hristien of your cook. The compradores, who have played such an important part in business in China, frequenty got, as much profit as do the heads of the busness firms. Everthing has to pass through their hands and they take their portion as it pesses. So it is all through the business rorld of china. every man takes his conmission on funds which he invests.

consequenty yealthy chinese are rather slow about investing their fortunes in lerge business undertakings such as mines and railroads. They have learned. that this is an excellent way of losing all one has. D. A. Ross telis of a corpary formed to bulid a certain railwey which maintained en idle staff of ten, and engaged station masters and jut them on the fay roll, before a rail had been laid. He tells of another case where 
tenders for sleepers were called for by one of the Goverment railways. The order vas given to a cerman firm which bid lowest. When more sleepers were wanted, the purchasing oficial telegraphed to the German firm, "Your Japanese competitor has come down to your figure, but you may have the contract for a moderate cormission." The German firm ignored the offer andad not receive the order. China is ful of such exceriences as these. She cannot develop her resources becuse her aishonest people cemot co-operate. Invested money disapears before business is coveloped.

China has depended for her support upon her. agricultural resources rather than upon her mineral wealth But almost every ye $r$ we hear of floods which destroy crops, and of the terrible famines which result. In April, 1912, it was estimated that in lorth Kiangsu alone there were 800,000 people facing death by starvatio, and that onIy bout ten yercent of this suffuring was relieved.7 In 1877-79, there was an awful famine and in two years no less than from ten to eleven millions of people died.8 Last year there as a flood in the region around Canton which destroyed many lives and moch property. The principal causes of these floods end consequent farines are four: (1) the country has been deforested, and after heavy rains the water irmediately

7. 19th en., x. 6iz4.

8. cutlook, 88:327. 
rushes down to the lowlande; (2) the river beds are full of sediment, and in some placos dykes have been built up on both banks to prevent overflow, and the sediment hos filled up the river bed until the bottor of the river is ebove the level of the land; (3) the population is so overcrowded that vast n mbers of people live from hand to mouth, and are unable to lay by anything for a rainfy day; (4) railrodds are undeveloped, and one frovince may be proscerous without being able to help a neighboring province which is starving.

The effect of this poverty-stricken condition of Chine upon her social Iife is evident.: The people are so occupied with gethering together enough money to buy their food for the doy that they have no time nor energy for the higher forms of social life. 'ihey have no time nor energy for education, for reading or for travel, and consequenty there is little cortunity for the growth of public spirit, national consciousness or patriotism. In the bitter struggle for existence, there is little chance for the development of the social virtues, mutual helpfulness and unselfish public service. "yvery men for hime elf and his family" is the rule throughout china.

Methods of Missions.

In meeting this situation, the methods of missionaries are of two classes: (1) philanthropic, seoking to relieve the present distress; (2) educational, seeking 
to remove the causes of roverty in China.

Philanthropic.

There are a number of chariteble institutions owned and maneged by the Christian church in china. The Roman Catholic lhurch posesses the majority of the se institutions, hoving in all 514 charitable institutions of various kinde. Frotestart churches in 1912 had 14 orphanages, 16 leper ssylums, 3 homes for untainted children of lepers, 11 institutions for the bind and deaf ruter, 5 rescue hores for fallen vomen and 2 judustrial homes." esides these regular institutions, fractically every rissionary does a certain amount of crivate charity work.

The non-Christian chinese themselves have a great many charitable institutions, and have had cheritable institutions for centuries. There are two principal motives in charity rork among the chinese. One is the desire to help those in need. The other is the desire to lay up rerit for one's self. The Chinese keeps a denit and redit account with Heaven, and believos that if he has comitted a crime he can counterbalance it with a proportionately great work of charity, and thus moke sure his hope of happiness in the next world! In the city of Soochow there are over fifty charitable organizations. These find expression in soup kitchens, founding homes, 9. Town, Chinese Tevolution, p. 99 . 10. Gee, Social outcasts, F. 3 . 
orphaneges, homes for the aged, and $r$ ief for widows in their own homes.

Some of these native charitable institutions are fairly good. The est one which I visited was an orphanage just outside the city of Soochow. Both boys and girls were received irl this institution. rhey studied for half a day, and did some kind of mainal labor the other half. The boys were taught useful trades cal culated to make them self-supporting. Sone vere making reed chairs, stools, tables, and other furniture. Others were making Chinese scissors. Still others vere weaving. The girls were taught to do housenold work and to sew. At the time I was there, they were busy making some clothes to send to some destitute children in the famine district. This institution wis clean and orderly. While it had been opened only three years, and one could not tell just hov succesul it really would be, it seemed to be a very good type of institution.!

I also visited the founding receiving and central stations in soochow. At the receiving station there is a drawer opening on the street by the side of the front door. This arawer is locked in the day tire, but can be opened from the outside at night. After a baby has been placed in it, the closing of the drawer rings a bell. This awakens the cere-taker who comes to care for

11. Already there was one young man who had ecome "institutionalized," and had come back to the orphange bec use he would rather stay there than out in the city. 
baby. Of course, the one who brings the baby at night pasees on and is never seen. The small sum of five cents is offered to any ore who will bring a baby in the day time and will tell the care-taker sonething of its history. This small sur is given to encourage people to bring unwanted baties and so to lessen the orime of infanticide. The baby is not kept at this receiving station, wut is taken from there to the central station. The central station keeps her (for they receive 600 girls and less than 100 boys during the year) until some home is found where the mother is willing to care for her in return for a small monthly allowance. She is visited at irregular intervals by an inspector who removes tie child if he finds it is not receiving proper care. In case of sickness the baby is brought back to the central station, and is treated by one of Dr. Park's internes." This is the only connection. this institution has with Christian mission workers.

The system semis to be a very good one, but both the receiving and the centrol stations were indescribably filthy and unsanitary. No accurate statistics as to the mortality rate were obtainable. But all of the babies who were at the central station at the time of our visit were in a fitiful condition.

Recently the leking students formed a social service club. This was inspired by the Peking Y. II. C. A., 11. South Methodist Iission. 
ut had no official connection therewith. In the same city a charity dinner was given long ago at the Industrial Institution for Indigent Boys. This is an industrial institution and free school which is purely chinese. Over five hundred homeless boys are cared for here. There are many such Chinese institutions in the country, some young and some ancient.

Thus we see that the Chinese are already attempt.. ing to meet the need of sone of their poor people. The function of the mission worker is to furnish to the Chinese people institutions and methods which may be models for them to copy. It is his rork to demonstrate the value of scientific philanthropy. The Chinese are naturally social minded when they are not pressed too close to the wall by the dire struggle for existence. Therefore they watch with the greatest interest any sociological experiments that are taken up, and are eager to learn scientific methods.

There is one such model institution in chefoo, a school for the deaf. A Christian Iresbyterian elder sent his deaf son to this school. The boy made great progres, and after leaving school, seoured a good position with the Cormercial Press, Shanghai. The father was so well pleased with his progress that he sent another son, who was not deaf, to the same school, who, on his

12. Nati. Rev. China, Feb. 16, '16. 
the people and make it difficult for them to settle back into hard work again. So the missionaries looked about for sorie form of preventive work.'4 A series of colossal engineering problems were involvod in the work of preverting future floods. Two great river systeris and some smaller ones have to be brought under control. The Yellow River has come to be known as "China's Sorrow" because of the havoc it has xlayed time and time again. The Yanetse seems sometimes to be as worthy of the name. Recently the River Hwai overlowed and caused famine in Anhwei and Kiangsu. The missionaries knew that this work was too immense to be done by them. Only the Government could effectively deal with problems so stupendous. But the missionaries felt that the most practical way of influencing the Government to undertake this would be $y$ giving those in power a demonstration of the value of such greventive work.

Accordingly in 191a, instead of eiving the famine sufferers relief gratis, every able-bodied man was given a job of work which would help to prevent the recurrence of the flood. In may of that year, 110,000 famine sufferes vere employed by the relief company, building and repairing dykes, cleaning out drainage canals, etc.5 Nothing was given outright except to the sick and feenle. The relief given not only relieved the immediate distress 
but helped to prevent the recurrence of the flood and famine.16

Deforestation.

Deforestation has been going on in China for several hundreds of years, conseguently the mountains in many places have been washed bare to the rocks. The soil has gone down the river and settled in the river beds in the plains, filling up the channels end making overflow easy with rooderate rainfall on the vare mountain sides. The country has not had enough tember for its ow use, and irmported nearly, as much in 1911 (5539,730 worth) as was obtained within its borders for furposes of local trade throligh the custorns in 1910 , (5641,696).'? Whe Chinese have not known the value of reclant. inf where they fell trees, or they heve felt that the trees they rlanted would soon be cut down by some one elst In Jaran it is contrary to law to cut dow one tree without ranting another in its rlace, no over the Japanese mountains you see a little tree growing near every stump. But the chinese rull e en the saplings by the roots for fuel. The English have set a good example of afforestation t Weihaiwai, and the cermans at Kiaochow, and chinese engineering and minine company at mongshang, Chihli. Sut the other chinese have paid little

16. Nation 94:360.

17. China Year Book, r. 45. 
attention to these good examples. A. Little said that "the deforesta ion of the hils and mountains is so marked and persistent that the demand for fuel and building alone will hardly explain it. 18 pere David believes it to be due to the dread of wild beasts and the consequent attempts to uproot and destroy their cover.

The University of Janking a few years ago secured an expert in forestry from the Fhilipines and began work in this subject.' This work received ouicial reconition and encouragement from the leking Goverment. This shool has acquired nearly a thousand acres on one of the barren rountains just out of vanking, and is planting on it tens of thousands of trees. There is no estimating the influence of a school of this kind in the cause of afforestation throu h its students who will he leaders in china.

But more important than any of these methods of missions for bettering the economic and industrial conditions of China is the reformation of the morel character of her citizens. Ge have spoken of the custom of "Squeering" and the well grounded suscicion with which the Chinese regard each other, and the resulting lack of development of her resources and her means of transfortation. Christian rissions are turning out young men wo ere strictly honest in their business transactions. 
The Chinese understan thet to become christian one must give up the pritilege of "squeezing". Our chinese cook in Shanghai refused to be a christian recause he said he could not be a cook and he a hristian. To him being a cook meant taking commissions, and heing a christian meant taking no comissions. Christianity and "squeezing" were incomptible, even in the mind of a servant.

$$
\text { Iany of these straightforwarch Christiar yung }
$$

men which the Church is developing in gina, are entering the business world and bringsing new moral fibre into it. Three Christian young men founded the Commercial Fress, Ita., in Shanghai, in $1897^{20}$ This press now employs 1,500 work peoxle, has a sound system of profit-sharing (kn 1910 the profits were $25 \%$ ), has a sahcool for the children of ermloyees, and has healthful surroundings' and sanitary conditions. It does someGovernment frinting and some newspaper work, but their business is principally the printing of text books.22+23.

20. Miss. Rev, of the Torld, Feb., '15, p. 145. 21. IOth Cen., 72:622. 22. Nineteenth Century, 7\%:62:.

23. hen I visited this press, just after the Revolution, curing which al men who vere loyal to the new Government had cut off their queues, some of the erryloyees were busy making their text books strictly up-to-date by cutting the queues off the coprer plates which had heen made for these books. 
CHALTER V.

\section{OPIUN}

Opium has been known all over the world as the curse of china. It is not only an incividuâl but also decidedly a social evil. Chinese society has been literally steeped in opim. This social evil is not indigenous in China, but has been introduced by foreigh trade. The Chinese work for opium, Alen, bears witness to this fact, as it is not a native word, but is only the chinese fronunciation of the English word opium. Another favorite name for opium in china is "foreign mud." There was a little opium smokin, in China before it was brought in by English traders some years rrevious to.1729. This opium had probably been introduced by the Fortuguese traders, but the quantity in use was very small, as there is no mention of it in the records of the early Roman Catholic missionaries?

But in the early part of the ighteenth Century, English troders came ux around the coest from India with their cargoes of ofium. At first they did not find a roady sale. So they used various means of cultivatirg the taste of the chinese for oxium. They reconized that China with its suffering, sorrowing millions, was a field prepared for the introduction of their soothing, deadening narcotic.

1. rewster, p. 265.

i. Ierwin, p. 31 . 
Then the Chinese Emperor took notice, passing an edict proclaiming the angers of the use of the drug, and forbidaing its sale in china (17\%9) . But the english traders kept on smugeling it in. In I7El the East India Company obtained a monopoly of the opium trade of India." Large quantities of Indian opium were brought to China. The Chinese Emperor made a more strenuous effort to stop the traffic. He rent $\boldsymbol{g}$ strong man, I, in Tse-hau, as Imperial Commissioner to Canton, with orders to take every measure necessary to stop the sale of opium there. Commissioner Lin began operations at once.' Bnglish boats containing 22,299 chests of opium were lying at anchor at Whanpo near Canton.' Commissioner Iin ordered the delivery of this oxiur. His soldiers approached the British offices, and the Britishers took to their heels, leavine the opium to the mercy of the Chinese. Commissioner Iin promptly dumped the opiurn (vallied at 9,000,000.00) into the sea? even as our forefathers did the tee of Eoston. Trade relations between England and China had al ready been strained, and this act f Commissioner In brought down upon China the ire of the British nation. The First Opium War $(1840-43)$ resultea. China was unpreparec to cope vith a modern nation. She was defeated and forced to sign the treaty of Nanking, which opened five ports, Canton, Amoy, Foochow, Ningpo and Shanghai.

3. Ross, c. $13 \%$.

4. rewster, Evolution of Jew China, p. 24.

5. Ross, Changing Chinese, p. 140 .

6. Nerwin, Drugeing a Nation, p. 40 .

7. Frown, New Forces in Ola China, p. 149. 
The island of Hongking was ceded to Great Iritain, and China was forced to pay an indemnity of $21,000,000.00$ for the opium and property destroyed and for the expenses of the war. Opium was not mentioned in this treaty, and of course, such peace could not be permanent. China made other efforts to throw off the poisonous ofiur viper. The second Opium War (1857-8) resulted, with defest for China again, and the treaty of Tientsin was signed, which gave to ritish subjects the right to trade in opium ir China.

It had become a very Iucrative trade. Warren Hastings saw in it hope for the fiscal policy of India. So the ritish Indian Government took over the opium monopoly. ${ }^{\prime}$. They recognized the pernicious nature of the drug, and early declared that its production was to be "permitted for the purrose of foreign commerce onl $v$." The British Government encouraged their Indian subjects to produce the poppy, loaning them money without interest for use in its cultivation. 10 The quantity yearly increased until by the close of the lineteenth Century it had reached rast dimensions." Iine-tenths of this vast rroduct was shixped to China.' ${ }^{2}$ The profit for the Indian Covernment was over $60,000,000.00$ yearly. $\cdot^{3 r 14}$

8. Merwin, Drugging a Nation, p. 20 .

9. lerwin, Drugging a lation, 22.

10. I erwin, Drugeing a ation, p. 25.

11. The total gain to the British Govennent from 1773 to 1906 has been estimated at \$2,100,000.00. Ross, F. 140 .

12. In 1906, 654,928 acres. Iermin, p. 26.

13. Amounting to 51,770 chests, 140 ibx. per chest. Merwin,p.26.

14. Brewster, Evo. of New China, p. 26. 
The Chinese Emperor saw how his people were being debauched and how his country was being drained of its silver. He determined upon another xolicy, suggested by Sir. Robert Hart, Director of the Chinese Imperial. Customs. He decided to permit the growth of the poppy in his cwn land, so that the home croduct could corpete with the foreign, and they could at lesst keec the money spent on opium within the Empire. They hoped also, when the opium used was produced altogether at home, to be able to suppress its croduction. They first informed England of this froposed policy, hopine that she would have mercy and withdrew her treffic in oxium before china resorted to this extreme measure. But England's ears had been deafened by the millions of dollars of revenue. ${ }^{15}$ So the Edict of 1990 went forth, permitting the growth of opium in China." If Itherto it hed been grown only in secret. Jow from east to west and from north to south, the news immediately spread, and in a afew years the showy blossoms were openly covering the rich river bottoms all over the Impire. The wholesome agricultural products were crowded out, especially in the provinces of the upper Yangtse, because nothing brought, so high a price or was so easily transported as opium. .

The use of opium increased grently. The imported product vas not driven out by home competition. A

15. Nerwin, p. 4\%. Ross, p. 140.

16. Moule, New China and OId, p. 93. 
higher quality of opium vas. produced in India, and the shops wied with each other in making palatable combinations of the various brands of oxium. No accurate statistics of the number of opium users are obtainable. A conservative estimate is that from one-third to one-half of the entire copulation of China became adaicted to the opium habit. In some rrovinces, which were known as opium provinces, conditions were rorse than in others. Szechuan, Shensi and chansi verefine worst. There was a saying in shensi that eleven men out of ten vere opium smokers.'7 In some cities almost every man; voman and child was a smoker. 18

Let us look for a moment at the ef'ect of the use of the opium. The Cantonese have Ten Cannots regarding the oxium smoker. "He cannot (1) give up the habit; (2) enjoy sleep; (3) wait for his turn when sharing is pipe ith his friends: (4) rise early; (5) be cured if sick; (6) helf relatives in need: (7) enjoy realth; 1 (8) plan anything; (9) get credit, even when an old customer; (10) walk any distance."'9 The late Dr. Griffith John, for fifty-six years a mis ionary in china, said: whe opium smoker ill lie, cheat and steal without the faintest sense of shame or wrong. In order to satisfy his craving he will sell of let out his wife,

1\%. Smith, The Uplift of china, $\rho$. 164.

18. Ross, Changing chinese, F. 141.

19. Ierwin, Drugging a lation, p. I7. 
starve his children, and steal the clothes off the hacks of his parents." 20 Orium undermines a man's health, his mind and his morals, and soon exhausts the purse éven of the vealthy.

Such was the condition of China. And what were the methods of that great band of missionaries in dealing with this stupendous social evil? At first they began $y$ seeking to redeem the individual. They had come to China for the rurpose of evangelizing individuals. So they brolight the opium fiend to the missionary physician, who gave him the opium cure." He went back home, the friends of his family came in, they rassed the opium pipe, the fumes began to fill the room. It wa more than the former opium fiend could withstand. Just for that once he smoked again, and the old habit was upon him with renewed force. Again he fought the battle, went to the missionary whome knew was his frie d in this struggle, took the opiurn cure again, came home, and after a little while fell back agin into the clutches of the old habit, for he was surrounded on all sides by temptation. Agán and again he tried. Again and again he failed.

Then the missionary began to realize the futilit: of the struggle for the individual opium smoker against such enormous odds. Me began to see that he must transform not only the individual but also the society in which

20. Contemp, Rev, 103:783-6.

21. From 90 to 95 of these cures were failures. 
he lived. Within the Church a firm stand was taken against opium. No one who smoked opiun, sold opiun, cultivated the opium poppy, manufactured any of its products, or rented rroperty for any of these uses, as allowed to be a member of the christian church. The evils of opiun smoking were proclained in the gulfit, in the home and on the street.

Fut the missionaries saw that their efforts could not be limited to their own church. They used the press in England against the Indian opium policy, and aroused public sentiment there and in sugland. Appeals were made to the British Farliament. Finally, in. 1896, Jarlian ent sent a comission to India to examine into the situation. But too much roney as involved, and the' commission brought back a report favorable to the export of opium. The large quantity of money derived from the opium traffic somehow made them think, or at least say, that opium and its products mere really beneficial to the chinese. But tire battle was not given up by the missionaries and friends of the Chinese. If in India the fiscal policy as at sake, in china the life of a nation was at stake. Anti-opium societies were formed everywhere among the Chinese. Members of ouch societies, pledged themselves to abstain from opium and to help to free others from the control of the drug. These societies constantIy grew in numbers and strength. he great national Antiopium Ieague of chine ras organized with gev. H. C. 
DuBose as president, and Rev. J. I. Hayes as secretary 22 This society appointed Dx. Park, of Soochow, to prepare a statement in regard to the effects of opium. He secured. the statements of one hundred and three missionary doctors in China, and published these in a book which had much todo mith the change in the views of Parliament. The climax in the vork of this great Anti-Orium Ieague cane when the Anti-Opium Memorial with 1,333 signatures of missionaries, was sent by it to the Empress Dowager, Tsu Hsi, in August, 1906. When there was no response to this memorial, the League sent its president, Ir. DuBose, in person to Peking. How great was the surprise of every one, missionaries included, altho gh they had een praying and rorking for just this, when there came forth that famous edict of the Empress Dowager, September 20,1906 , in almost the very words of the memorial of the missioneries. It provided that: (I) the sovernors of the provinces ascertain the exact number of acres undes poppy cultivation, and cut dom that area one-ninth each year; (2) that all smokers go to the nearest authorities to get certificates, in which they are to write their names, addresses, professions, ages, and the amount of opium smoked each ay. All of those under sixty must get cured before they are sixty. No more certificates were to be issued. One-third less was to be sold to 22. Farker, Old Order Changing in Changeless China,p. 9. 
(99)

these each year. (3) All rublic races for smoking gium vere to be closed and no new stores orened. (4) All officials end officers of army and navy, and professors of schools and colleges and unive sities had to get curea within six months. (5) It mas decided to open negotiations with Great Britain, arranging with that power to have less and less opium imorted each year, till at the end of nine yoars no pore opium would be imported at all. ${ }^{23}$ rany doubted the efficacy of the edict, especially the British traders. Everybody, remembering the inefficiency of the Chinese Government six decades before, and the numberous edicts since, was wondering what would be the outcome. Fut this was not the china of six decades ago. China's pride had heen hurt because she found herself weaker than other nations. Japan had been able to defeat Russia. Why was China so weak? The answer everywhere was, "Opium." And new public spirit had arisen. If patriotism hitherto unknown was felt. The sleepine giant was begioning to stretch his muscles and feel the new life hich has been transfused into his veins. Heretofore the slogan had been "Wvery man for hinself." Now the cry was, "We must give up opium for the sake of China.": The leavening of the gospel had penetrated wore perfectly into that immense mass of humanity. Much of the "salt of the earth" had been 23. Terwin, Drugging a lation, . 87. 
sprinkled from one end to the other of that decaying empire.

Dut it was no essy task. The officials and the soldiers who were ordered to eradicate opium vere themselves addicted to the habit. But the Government was firm. Every official, except those over sixty years of age, vas given six months to stop the habit or be expelled from office. Wach one vas placed in a cell for a three days test. He was given food and water but no opium. The most determined could not stand this test. Before the three days were up, if he had been an opium smoker, he was on his knees to the attendant begging him for opium. 24

An irmense anount of Indian opium was being shipped into China. ${ }^{25}$ nother appeal wa made to Ingland by the chinese overnment to stop the importation. Again the was no response. But the thglish public had been aroured. The Anti-opium societies had created public sentiment in England against the opium traffic. Iumbers of gnglish people protested against the action of the Government. Fhen the change come(1907), and Inglard, in view of the "manifold and weighty evidence" against opium, agreed also to reduce her inportation one-tenth each year until at the end of ten years the traffic would stop, if chine proved sincere. $2 L$

24. Ross, pp. 161-2. 25. Brevster, p. 104 . 26. Ross, P. 170 . 
Throughout china the fight against oxium went on. In different provinces it met ith varying fortunes, depending upon the caliber of the officials in charge. But on the whole the progress was faster than those most interested had hoped for. "In March, 1909, Viceroy Tuan Fang recorted that 3,000,000 people had given up the opium hit since the issuance of the decrees, that opium rnokers had been reduced $65 \%$, and that the cultivation of the ropry and the revenue from opiur had been decreased one-half. The Government had sacrificed from $100,000,000$ to $150,000,000$ taels of revenue. "27 When Dr. DuBose, first president and chief instigator of the AntiOrium League of China, died in 1909, already two-thirds of the orium dens of china had been closed. "This daring and chivalrous soldier of the great ideal lived to see the approach of the consummation of the noblest ministry a white man ever rendered China."

Meanwhile, the Indian orium continued to come in. The Chinese were supressing its growth in Chine even rore quickly then they had lanned. The misionaries conld not rest. Fhey continued to agitate the opium question, both in China and in their home lands. The International Reform Bureau, of which Ir. $\mathbf{x}$. H. Thwing, missionary in Morth China, was chinese representative, had taken up the opium question as $d$

27. China Miss. Yr. Bk., 1910, unoted in Ca.en, p. 177. 
international roblem as early as 1004 . Now this ureau asked iresident poosevelt to appeal to ingland to stop the importation of opium into China even sooner than they had agreed. At Mr. Roosevelt's instigation, the International Anti-Opium Commission met in Shanghai in 1909. This comission had not the power to legislate, but only forer to investigate and to fass resolutions suggesting ways and means of suppressing the opium traffic. Of this commission Dr. Arthur H. Smith said, "The great opium conference of 1909 in Shanghai feused the sentiment of the morld against this deadly arug. il 28

The Chinese were suppressing the home product nore rapidy than the British were decreasing the quantity of imported opium. So another appeal was made to England, and in due time another treaty was signed, in which England agreed to stop the importation of opium into thos provinces where the Chinese had stopped its growth, and to stor the entire import before 1917 if China succeeded in her efforts to suppress its cultivation. ${ }^{29}$

The fight against opium in China gained such headway, that the chinese began to ask that no more opium be imported anywhere. The two treaty ports of shanghai and Canton were still open. The Chinese officials had

28. Contemp. Rev. 103:783-6.

29. In 1911 . 
become so deeply in earnest that even in these two ports opium was not allowed to enter. Accordingly it began to accumulate in the two harbors. It was coming in at the rate of 2,000 chests per month, and very soon an enormous stock was accumulated. In July, 1913, there vere 6,000 chests in these harbors, with an estimated value of $75,000,000.00$. The banks in Shanghai Ioaned money on this stock to the amount of $\$ 50,000,000.00$. These Shanghai bankers and the Indian merchants believed that the zeal of the anti-opium enthusiasts would soon abate, and the opium could soon be imported at enormous profit.

But the Peking Government was firm. The

Chinese press was by no means uncertain in its expression of opinion. The large missionary body and the chinese Christian constituency were faithfully continuing the crusade begun half a century before. The chinese local officials smiled blandly at the opium merchants, but did not allow the opium to enter. Finally, however, the cause of the merchants won, and the opium was allowed to enter, in return for payment of surtax of $21,000,000,00$. The grapple with the opium evil is still on in China. There are large quantities of buried opium all over China in sufficient quantity to furnish a moderate supply for years to come. Other opium is being smuggled in along the coast from India, and along the western border from Tussia. Pesides this opium, there are the 6,000 chests of opium stored in the trety ports (Shanghai 
and Canton.) But in sxite of all this, the progress has been steady, as the following statistics testify:

THE QUARTERLY RETURIS FOR DUTY ON OPIUN, FRO JULY TO SEPTAMBEP, 1914 and 1915.

Duty

Chinese Flag

Foreign Flag

Likin

Chinese Flag Foreign Flag
1914

T15.7,798

136,790
1915

TIs. 639

76,323

$$
\begin{array}{rr}
9,618 & 1,597 \\
341,946 & -190,820 \\
\hline \text { TIs. } 496,153 & \text { TIs.269,381 }
\end{array}
$$


CHAFTAR VI.

POIITICAL CORRUI IOI. AND OTHER INTORAIITY

"Squeezing and Pribery in Fublic Iife.

R. R. Douglas has said that "universal dishonesty of mind poisons the sap of the nation, and produces all the cancers and evils which have made China a by-word for deceit and corruption. " ${ }^{2}$ Corruption, bribery, "squeezing," the taking of surreptitious commissions are expected of all officials in China after they are in office. Their salaries are insufficient to meet their expenses. Whis fact is known by the authorities who appoint them and it is allo known how they will make up the deficit. They do not enter office clean hondea because they obtain appointment through hribes and they expect to get all they can out of their offices during the time they halve them. Mr. Holcombe, our late secretary of Legation at Peking, says that the necessary expenses for a Chinese viceroy, not including remuneration for his services, are at least $\$ 50,000.00$ a year, while his salary and legitimate allowances amount to $6,000.000^{2}$ the taking of uribes and secret commissions or "squeezes," seem necessary for him if he is to make both ends meet. If he is a reasonably honorable man he will take a sufficient amount to meet his expenses nd ray for him for his services and

1. Douglas, Society in China, p. 84 .

2. Outlook, 82:789. 
will pass the rest on to the proper authorities, but if he is dishonest he will was on to the higher authorities what he thinks will be required of him and keep all remaining of the amount that he has extorted from the people uncier hirs.

It is estimated that the officials steal fourfiftis of the taxes in china. The office of tax-collector is sold to the highest bidaer. For instance, the auty on kerosene and matches in Kwángsi was let out to a syricate for twelve years by proclamation. The amount of tax money which this syndicate agreed to ray to the government mas $10,000.00$ a year. The taxes anounted to twice that sum. A part of the extra $\$ 10,000.00$ went back to the mandarins in bribes and presents in return for the contract and the remainder was retained by the syndicate. The goverment has a monopoly on the salt industry of China. The irportation of foreign salt is forbidden by treaty. The chinese ob ain their salt by evaporation or from the salt vells of Szechuan. The people consume 25,000,000 piculs of salt yearly for which they cay 81,000,000 taels, of which 64,000,000 is for taxes. Of this mount only 13,000,000 taels reach the royal treasury. Of the remainder 26,000,000 taels go to the provincial officials and $25,000,000$ to the $100 a 1$ dministrutors. When in 1912 the Chinese government received heavy loans from foreign governments, the foreign 3. outlook, 82:789. 
governnents relied upon the salt monopoly for their repayment and-designated an Inglishman to collect the salt taxes. As a result the imperial returns in 1912 were nore than three and one-half tires as great as before, amounting to $47,575,486$ taels.

The magistrates and other officials yell even take part of the fund passing through their hands intended for the relief of famine. One year a tao-tai put amay one hundred'thousand dollars, "for he had a chance at the famine funds. It is hard to the extent of the corrurtion of a man who would steal from starving. thousands of his fellow coutrymen in order to pile up riches for himself.

Brinery.

The bribes which a magistrate receives in the adrinistration of the laws are one of the sources of income upon which he depends. s a rule throushout China the one who cun make the larest present to the official is the one who gets the decision in court. If the official is a gentieman he may return the rresent of the one aginst whom the decision has been rendered. In 1906 when the Chinese Judge of the Shanghai Mixed Court was throw out of office it vas found that he had accumulated a fortune of $\$ 1,750,000$ gold from the bribus he had received. 4

Christian missionaries cannot interfere with

4. Outlook 82:720. 
the government of China. Rgman Catholics have gained an ill-fevor in China because they have tampered with politics. But the hristian mission can produce chinese Christian statesmen who may in time remake the government of china. Before the revolution there was little chance for a christian in the chinese government, but the revolution brought a marked change. It vas estimated that three-fourtis of the revolutionists had been influenced in some way by Christianity. At one time sixty members of the new senate were christians. Dr. Sun Yat-sen, the first provisional president of the republic, General Ii Yuan-hung, commander-in-chief of the provisional amy and provisional vice-president of the rexublic, Wang Chong-wei, nister of foreign affairs, Tay Chi-ho, rivate secretary of Sen Yat-sen, were all professing Christians. In Fukien province the government was vested in eight commissions, the presidents of four of which were Christians. One of these, Nong Ti-siong, the president of Posts and Communications, has been an active christian for thirty years and has frequently preached. in Christian churches. Another, Ding reng-gueng, the president of Foreign ffairs, is an ative Christian and a graduate of a mission school. Wen Shih-tsen, cormissioner of Foreign Affairs of Chekinns is a christian, as is the governor of Kiangchou in Kan Su?

Another Christian who has had an interesting

5. Miss. Review of the World, Jan. 1915, f. 5. 6. liss Review of the Vorld, 191\%, x. 625. 
political career is Mr. C. T. Wong. This young man was educated in America and after graduating from Yale with high honors returned to China as secretary of the Y. II. C. A. At the time of the revolution he went to the front to offer his life for his country. He was a member of Gener Ii's staff and acted as minister of foreign affairs in the provisicnal government. He was a member of the rovisional senete under Sun Yat-sen and acted as his fersonal representative in the handing of some important affairs. Under Yuan Shi-kai he was called to be acting minister of commere. He was elected vice-president of the new senate in Peking and labored. "with high purpose and sklendid splendid self denial as a burning fatriot for the welfare of China."

Untruthfulness.

It is the universal testimony of those who have dealt with the Chinese that they are untruthel in the extreme? Pruth is not one of the social gracés of cha. Untruthulness produces no sense of shame in the Chinese breast. The little children are taught that the cleverest child is the one who can tell the biggest lie without getting caught.

In my work in the Embroidery Mission in West Soochow I often had to deal with the shop-keepers-men who sold the materials which our vomen embroidered. 7. Krausse, China in Dec y, p. 26; Capen, Sociological Frogress in lission Lands, p. 160; Smith, Chinese Characteristics, p. 161 . 
These men had not been touched by christianity and were apparently absolutely lacking in any sense of the value of truthfuiness.

One of these men brought me a bolt of silk 'to match a samle I had sent him. I could see at a glance that the silk did not match and I did not hesitate to tell him so.

"Yes," he answered, "this is exactly the same piece that sample was taken from. This is the bolt from which I cut that first xiece of cloth."

"But this bolt has not the sheen that first, piece had and $I$ know it is not the same."

After repeating his first statement several times to no avail he thought he would try another story. "Well," he said finally, "this isn't the s'ame piece, but it will have the same sheen if you dye it." Then he could not convince me of this story he made another effort, this time, I believe, telling me the truth.

"I'Il tell you; we haven't any silk in soochow like thet you what, but if you will buy six bolts, I will order it from another city."

He had told me three contradictory stories in succession and did not seem the least bit ashamed of abandoning any of them if he found it did not suit his furpose. And so it is with all non-Christian Chinese. Chinese society discense with the natural avantages of 
the reliable written or soken word.

\section{Christian missionaries teach their converts}

the advantages of truthfulness and the duty of heing truthful. This has some effect uron the Chinese christians They are more reliable than the nor-christians. But their old standards have been so deefly engrained that they are far from ferfect in this regerd. In Natters of flattery they are aderts. They are also untruthful in more vital matters. They tell the missionary what they thirk he mould like to helieve true. Then the missionary discovers later that this is not true and makes inquiries, the Chinese Christian says: "Yes, I knew that was not true, but I knew that was what you wanted to be true," or "I knew that was what you thought to be true." And yet there is much progress in truthfulness. It does not come so easy to the christian to be untruthful as to the non-christion. While there are times when he slips back into his old aecitful way of śeaking, there ope also times when he is heroic in upholding-the truth. That missionary is fortunate who can see the growth in truthfulness, who can understand sorething of the dexths of rro which his converts are rising and can sympthize with them in their victories. The missionary ne ds to understand these things in order that he ay not lose hope of ul timate yictory and in order that he nay be exceedingly and unendingly ratient in fostering the growth of the standard of truth amone the Chinese. 
Gambling.

Gamis ing has been referrod to as the national vice of China. Beggars uill st ke their last scrap of elothing; fanatics will stake wives and children; men will wager away their finger joints. cne of their favorite vays of gambling is over the hiras which they cerry about Witr them in cages. One of my first mornings in Shanghai I was awakened by the sound of many birds singing. I was soon informed that these were the bircs with which the men gambled and on looking out of the window I saw a number of ren each caring for his bird in its cage and hanging it ux in the trees where it culd look at the green fields of the race course nearby and sing. I very seldom went out on the streets without seeing several men with birds in cages for gambing purposés. The Chinese gamble about everything and all. classes, men, women, and children gambie.

It hos been alleged that one of the causes of the frevalence of gambing in Chine is the separation of the sexes and the consequent dullness of social intercourse. The men to make the pasing of time a little less tiresome grnble on the streets, in the tea houses, everywhere. The women, shut up in the houses, have found ife even more horesome and engage in gambling over carde and dominos from morning until night. Accompanying the avakening of conscience of the 8. Leroy-Beaulieu, The Amakening of the tase, p. 224. 
opium evil, there also arose some native opposition to the gambing evil as the folkowing quotation from the National Review (Shanghai) testifies: "The general awakening of the country to the sepiousness of the ofium evil has been fruitful in other directions also. A general awakening of the noral sense ceems to have taken $x$ lace and so, contemforaneous with the opium campaign, there has been an attack on another of the traditional indulgences of the feople, namely the garnbling evil............. In some provinces, notably in Kwangtung, the authorities have not scrupled to make this national proclivity for games of chance a source of income and for many years Iicensed gambling houses have contributed no small sums to the provincial revenues. Juring the last two ye rs the people of canton, led by the younger officials and the advanced section of the erucated clas s have sought to get rid of the gambline evil and have chosen as their first point of attack the Iicensed houses. The late viceroy, unable to find a source of revenue to take the place of the threatened genhing licenses, temporized and learned the truth of the roverb that he who hesitates is lost, for eventualy he wa removed from office largely on account of his attituae on this question." 9

The Christians have been setting an exarple to the other chinese, for they are required to give uf gamiling. Nany Christians wero inveterate gamblers before

9. The Nat. Review (Shanghai) quoted in Brown, The Chinese nevolution, x. 150. 
conversion. In the large testimony eetings following the big tent meetings there hundreds begin to be christians, one of the most frequentiy heard testimonies. is: "I was a garbler, but I have stopped gambling." "The Christians in a certain village in china seemed to a missionary to be making little progress, but one of the proinent church members said, "Sir, you don't know. Formerly, before we heard the truth, gambling was common; rov it has been entirely arolished." 10

$$
\text { Eut there is opportunity for wider service. }
$$

The non-Christian Chinese are waiting for leadership in the direction of the gambing evil. The christian communities could furnish this leadership. As is evidenced by the quotation from the lational Review (Changhai) the chinese who were interested in putting down the ofium evil are also interested in suppressing gambling. Waung Ta Ta, an elcierly Chinese lady in Scochow, who was one of the leacers in the anti-foot hinding crusade, is not trying to create interest in an anti-gambing crusade in that city. If the christians woula unite in angi-gambling crusades, I have Iittle dount that they would ultinately met with success. (The Chinese lady just mentioned hoped to get the help of the Cristians, but the Christians did not refpona.y such a practical demonstration of what it means to be Christians would he one of the most effective ways of rreaching the gospel. As a rule the Christien 
(115)

community is too self-centered and does not look out over the community to see what $c n$ be done in the way of city inprovement. 


\section{CONCIUSICN}

Christianity in China has had a gradual undermining influence uxon the great social evils. Net one of these has escaped the leveling touch of the new religion. This effect has been accomplished first of all through the indivicual. Nissionaries, as a rule, have not gone to China, with the curpose of transforming Chinese society, but to rescue individuals. From time to time in the ir efforts to save the inaividual they have been drawn into the struggle against the social evils. They have succeeded in combating these just ceause they did not begin with the individual Chinese. lo other flan would have been effective. And when missionaries have even more fully realized that every individual should be given along with high ideals the means of rutting them into practice and have consciously developed in him a desire and an ability to do social service and to attack definitely the social evils of his environment and to uplift the social life of his country, progress in the development of Chinese society will undoubtedly be more rapid. Tissionaries should consciously take up the work into which they heve merely driftec heretofore. They should thoroughl investigate the social conditions and social evils of China and strike directly at them. They should aim not only at the regeneration of the Chinese individual, but at the regeneraticr of Chinese society, 
until the customs and institutions of chipare such as help rather than hinder the christian ran in the practice of Christian rrinciples.

The growth in the number of Christians in China has been almost unbelieveably racid. Robert llorrison care to China, in 1807. Nilne, his successor, one of the most hopeful men of his time in regard to christian missions in China, had faith to relieve that in another century there would be as many as one thousend Frotestant Christians ir China. ' Instead there vere more than 100,000. Within the last eighteen years the number of chriatian converts in China has dolibled. In 1915 the number of these was 356,200 . If the increase in the future is as rapid as in the past, within a century China will be Christian. "No one knows how great will be the power of China in that day. Those who live and work with the Chinese feel that their strength and arility is as yet urmeasured. It is estimated that China contains onefourth of the poxulation of the gloe. The Christianization of the social life of that vast copulation, with its high type of intellectual fower, is an uncertaking fraught with stupendous possibilities. 


\section{BIBIIOCRAIHY}

Beach, H. P., Daw on the Hills of Tang or Ilissions in china.

Bell, H. T. lontague and H. G. Wo Woodand, hina Year BOok 1913 .

Bland, G. O. P. and ${ }^{2}$ : Backhouse, China under the Bmpress Dowager.

Bliss, Edwin lunsell, The Missionary Enterpise. Bohn, Henry $G_{.}$, China, Descriptive and Historical. Brewster, Wm. IT., The Evolution of lev China. Broominal, 1.. Chinese Empire. Brown, Arthur Judson, New Forces in Old China. The Chinese Revolution. The Foreign Missionary.

rulletins of Ginling College, Nanking, China. Burton, largeret \pm . The Education of "loman in China. Eushnell, Albert, The Obvious Orient. Capen, Edward Varrer, Sociological Frogress in Mission Lands. Catholic sncyclopedia sub China. Chang Chih Tung, China's only Hope. Clough, John E., Social Christianity in the Orient. Cochrane, Thos., Survey of the Missionary Occupation of China.

Colquioun, Archibald Ross, China in Transformation. 
Dawson, Grone, H, Ming lisien Chi, Being a Collection of roverbs and Maxims in the Chinese Ianguage. Dennis, James S., Christian liśsions and Social Progress. Foreign Missions After a Century. Dewey, John, The School and Society. Doolittle, Justus, Social Iife of the Chinese. Dougias, Sir Roiert K., China.

cociety in China. Dowd, The Negro Races. Ecumenical Missionary Conference, Hew York, 1900 sub China. Ellvood, Charles A., Sociology and Iodern Social Froblems. Faunce, W. H. F., The Social Aspects of Foreign lissions. Gee, Iathanael Gist, A Class of social Outcasts, eing a Brief study of the Peggars of china.

Gibson, J. C., Miscion Lroblems and Mission Methods in South China. Giles, Herbert A., The Civilization of China. Goodrich, Joserh King, The Co ing China'. Gowan, Herbert Henry, An Outline History of China. Grant, G. I., The Religions of the forld. Hesland, Isaac laylor, Court Iife in China. Nome Life in China. Hersey, Roscoe li., Social Service. Houghton, Ross C. Women of the orient. Keane, A. H., Asia.

Ethnology Nan Past and Present. 
King, Harry Edwin, The Educational System of China as

Recentì Reconstructeá.

Vrrausse, Alexis Sidney, China in Decay.

The Far East: Its History ana its Question.

Legge, James, The Sacred Books of China,

The Texts of Confucianism.

Leroy-Beaulieu, Fierre, The Awakening of the East.

Lewis, Robert $\Xi$. , The ducational Conquest of the Far gast.

Iittle, Archibaldj., Through the Yangtse Gorges.

Macgowan, J., The Imperial History of China.

lartin, W. A., The Awakening of China.

The Chinese: Their Education, Philosophy and Letters.

The Lore of Cathay.

Vathews, Shailer, The social eachings of Jesus.

Kroltabr, R. L., The fomen of the Iidale Ki ngdom.

Merwin, Samuel, Irugging a ITation.

Moule, Archdeacon, Mew China and $01 \mathrm{~d}$.

Parker, A. F., The old crder Changing in Changeless China.

Ratzel, The History of I ankind.*

Reclus, The Earth and Its Inhaitants.

Records, China Centenary Ilissionary Conference, 1907.

Report, Board of Foreign lifissions, M. E. Church, S., $191 \mathrm{~b}$.

Report of the First Conference of Secretaries of the

Y. I. C. A. of China and Korea, II

Ross, Edward Alsworth, the Changing Chinese. Social Psychology.

Scidore, Eliza Ruhameh, China, The Long-Lived Empire. 
Slater, O. T., Iissions and Sodioloy.

Smith, Arthur H., Chinese Village Iife. "Chinese Characteristics.

The Uplift of China.

Stanfora, Compendium of Geosraphy and rravel.

Stirling, W. G, Opium Smoking Among the Chinese.

Taylor, Alva w., The cocial Work of Christian I issions.

Taylor, craham, Peligion in Social Action.

Thomson, J. S., The Chinese.

Williams, Samuel Tells, A History of China.

Feriodical Iiterature.

Bashford, James $V$. , The Economic Significance of China's

Evangelization, Iiss. Rev. 19:35z-4 Ny. 106.

ctamping out the Flagues in China. Cutlook 98:249-5]

Beamar, W. F., The Union Educationel Scheme of Western

China. Miss. Rev. Ny: 09, F. 368.

Eible, F. W., The Importance of Educational Nissions in

China. Niss. Rev. 2i:682-4 s. '109.

Bicknell, irnest $H$., Famine Relief Vork in China.

Curvey 29:900-2 Mr. 29, 113.

Blake, E., Fosition of oman in China, leth Cen.

72:1040-51 N. '12.

Bone, C., Avakening of the Homen of China.

Ind. $75: 667-70$ s. 18,13 .

Brandt, 1. Von, China's Problems, Ind. 54: ¿580. 
Cacen, E. W., Nodern Frinciples of Foreign Missions. Annals Amer.. Acad. 30:461 F.

Sociological Appraisal of lestern Influence in the orient. Am. J. Soc. 16: \$34-60, 1y. 'II.

Century, $82: 430-47 \mathrm{~J} \cdot \mathrm{C} .11 \mathrm{l}$

Chaut. 64:11-12 S. 'II. The Anglo-Chinese Op ium Agreement.

Cheng, hentung Liang, Iission Work and Eaucational

Reform in China. Inder. 55:1846.

Chiles, Rosa lendleton, The Fassing of the Opium Iraffic.

Forum 46:22-39 JI. '11.

Collins, Wr. J., The Opium Conference at the Hague.

Contemp. R. 101:317-27. My. 12.

Contemporary Review 103:703-6, J1. '13. Opium: An Unsettiea guestion.

Cressy, Earl H., Some Socal and Economic Results of the

evolution in China. Survey $29: 33-6$.

Current Literature 33:100 J1. 'O2. Woran's Rights in

China.

Denby, C., Chinese Trits and Usage, Cur. Tit. 31:94-5. J1. 'OI. Ifidy, sherwood. sia Awake and Arising.

Vorld's work, 26:400-13. Aug. '14.

Giles, H. A., Woran in Chinese Iiterature.

Ioth Cen. $56: 20-32 N \cdot 14$.

Grant, W. Henry, Christian Education in China.

Record of Christian Work Ir. 109 r. I6 F.

Hadden $i$.., e ing in China, our. Lit. 32:679-80 JI. '02. 
Hol combe, Chester, The Missjonary Enterpise in China. Atlantic lonthly $9: 348 \mathrm{~F}$.

Hosie, Alex. The Salt Iroduction and Salt Revenue in China. loth Cent. $75: 1119-43 \mathrm{Ny}$. '14. VHoste, D. C., The rissionary and His Relation to the Treaties. Chinese Recorder, Dec. 108, 671-6. Fume, Lotta Carsmell, The Social Service Ieague of hangsha. The Survey $34: 575-7$.

Independent, 68:480-90, Nr. 3, '10. The End of the Opium Curse. 70:1076- Ny. 18, '11. Habit-forming Drugs. 70:927-8Iy: 4,'11. 0pium in China. 73:899-901. 0.17,'12. Suicide jn China. 74:156. Ja.16,'13. Mine Stages in Chinese Peform. 74:560-1 My. 13, '13. British Opium in China. Inglis, Jas. ., A Chinese Cfficial iew of lissions. riss. R. 20:135-7.

International Review of lissions Vol. 1, 2, 3, 4, 1912-15. Jameson, C. D., The Future of China Cutlook, 8:475 J1.'II. Johnoton, James, The Unorowned King of athay.

Iiss. Rev. $21: 822-4$ I. 108 .

Kahn, I., Girl Slavery in China. Ind. 53:1605-8, Jl.'Il. Kelly, Tracy R., The lieed of China. lration 94:360-1. Kennan, George, China in Transition. Cutlook. E2:rer. Kinnosuke, Adachi, Iew Woman in China and Japan.

R. of Rs. 46:71-3. JI. 'I2.

Le ong Kai Cheu, Awakeing of China. Ind. 55:1267-8. My.28, '03 Lewis, Robert $\mathrm{z} .$, The Mmoress Iowa er's System of lodern Colleges for China. P. of Rs. 26:"2. 
Literary Digest 45:510 S. 28, '12. Clina's Hygienic Aspirations. 46:173-4 Ja. 25,'13. Chinese cuppression of crium. 46:1432.J1. 28,'13. The Knock-out Blow for Opium. 47:370-1. S. 6, '13. China Forces England's Hand on the Opium question. 48:421-2 F. 28, '14. tandard Oil and China, Farners. 4:1050. Iy.2,'14. Vanual Training for Chinese Christians. 49:264. Ag. 15,"14. Opium Erchibition in China.

Little, Mrs. Archibald, Chenter, Iiving Age. 240:548-5 F. $27,104$.

Ijving Age. 251:239, 1906. "Progress" in China. 269:755-8

i1. 17,'11. The New Opium Convention. 273:442-4 My. 18, 'Iz Chinese Girls.

Nocht, DavidI., The History of Opium, Sci. Amer. S. $70: 350-2$. Hy. 29, 115 .

llartin, W. A. F., China Pransformed. Vorld's W. I2:7844. The Awakening of China. W. W. 11:7124. Missionary Review of the World. Ny.109. The Celestial Empire Census. p. 391 . Revivals in Central China, p. 323. Chinese fomen Coming into their Own. Chinese Girl Graduates in Medicine. 24:524-6. JI.'II Eduction of China's Daughters.

Vonroe, Harriet, The Training of Chinese Children. Cent. $83: 643-52 . \mathbb{M r} \cdot{ }^{\prime} \mathrm{A}$.

Morse, A. SI Grases of China and Chinese Homes. IJation $76: 18, \mathrm{Ja} .1,103$. 
Nation. 90:474-5. 1y.12,'10. Trogress in China.

National Review (China) Jan., Teb. 1916.

Open Court, 20:58\%, Chinese Industries and Foreign Re-

lations. 20:668, Childhood and Education in China.

Osgood, e. I., No little Girls count in China?

Miss. Rev. 20:843-6. N.'07.

Outlook 5:8E5, JI. 11, '10. Slavery Emancipation in china

98:377. J1.1\%,11. Women in China. 100:711-2,

Ir. 30, 'I2. The International Opium Conference.

100:755-6. Ap. 6,'Id. The Civic Tork of Christianity

102:237-2. 0. 5,'1\%. Chinese Finances. 10\%:ry00-1

N. 30,'I2. The Industrial evelopment of China.

104:547-8 Jy. 12,'13. The International Opium Con-

ference. 107:583-4. JI. II,'I4. Opium Erewing in

China. 110:8-9 My.5,'15. pium.

Parker, A. F., Letter from China, Facific Nethodist Advocate. June $19,1913, \mathrm{p}, 6-7 \%$

Fotter, H. C. Chinese Traits and Vestern Flunders. Cent.

$60: 921-30.0 .100$.

Reid, Cilbert, Missionaries as Amenalle to Chinese Law.

The Chinese Recorder. Dec.'08, p. 676-80.

Reinsch, Faul S., Cultural Factors in the chinese Crisis.

Ann. Amer. Acad. $16: 435$.

Reviev of Reviens, 31 :595, China's Slic ess in Her War on

Opium. 4I:224, F. 'IO. Nedical Nissionaries in

China--A Japanese Appreciation. 44:22I-2. Ag.'II.

China's Success in Her War on Opium. 42:605-6 I.' '10.

The Powers and the Opium Question. 
Richard, Timothy, The New sducation in China.

contemp. $83: 11,1903$.

Ritzman, I. E. Woman's Ife in China.

Miss. R. 24:93-10I. F.'II.

Ross, E. A., Sociological Observations on Inner China: Am. J. SOc. 16:721-33. I"y.11.

Scheltema, J. F., The International Cpium Conference.

Westminster Review 175:613-2心, Je.'11. The Opium Question. Am. J. Soc. 17:213-35. S.'10.

Scientific American Eupplement. 49:20388 $\mathrm{My} .19,100$.

Opium Iroduction in Fersia. 54:22213. II.26, '12.

China's Unbandaged Peet. 57:23412-3. Jan.2, 04.

In the Iand of opium: 74:414. D. 28,'12. China

Suppressing the Opium Habit.

Shav, yarnest $T$., Public Institutions for the foor in

Ieking. Survey :32616-1\%.

Sheffield, I. Z.. Treaty Frotection to Christian Missions/

in China. The Chinese Recorder, D. '08, 657-71.

Sheppard, $G$. Whe Christian fyologetic for China. The

Chinese Recorder, D. '05, 680-91.

Silver, Emma, The Chinese Horre and Family.

The Association Ionthly, My. 109, 175 F.

Singh, S. I., Changing status of oriental Nomen. Edin.R.

$216: 163-86$. JI. 'I2.

The Iassing of the Indo-Chinese Opium Trade.

Living Age. "r9:30z-6. N.'13. 
Smith, A. Corbett, Some Aspects of Chinese Reform. 19th Cen. 72:615-26.'S. '12.

Smith, Arthur H., The Christian church in Changing China. Inter, Rev. of Iiss. 4:96 F. Jan., 1915.

Smith, Thomas, The United Universities Scheme for China. IYiss. R. 24:673-6. S.'Il.

Speer, Pobert I. $_{\text {. The }}$ Teneral Environment of Missions in China at the Present Time. Inter. R. of M. 4:96 F. Jan., 1915.

Tajlor, r. C., Opium: A live uestion. Contemp. R. loz:

40-8. Opium: An Unsettled question. Iivirg Age $278: 103-6$. J1. 12,13.

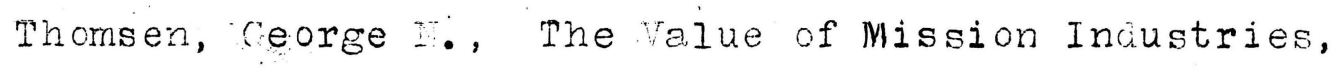

Iiss. R. of W. $21: 365-6$. My.' 08 .

Tong, H. K., China Versus America. Ind. 82:117-19.

Ap. $19,115$.

Towns, Chas D., The Peril of the prug Habit. ent. $84: 580-7 \mathrm{Ag} \cdot 12$.

Tsao, Y. S., China's Revolution Spells Progress.

Miss. R. of W. 24:919-25 D.'11.

Wang Ching Chun, How China is Tighting Against Opium. Forld Today 19:769-73. J1. '10.

Veshburn, Elizabeth. The Passing of the Opium Question. Outlook 106:365-8 F. 14, '14. Webster, I., China and Vor Feorle; J"snners and Customs, labits and Lives. Sci. Am. S. 50:20625-6.\$. 1,00. 
(128)

Wong Jin Ying, Story of, a Petrothed Chinese Young Lady. Ind. 55:2167-70. S. 10,103.

Worla's Work 23:135-6 D. 11. A new China.

right, Hamilton. The End of the Opium question.

R. f Rs. 51:464-6. Ap. il5.

Wu Ting-Fang. The Causes of the unpopularity of the

roceigner in China.

Ann. Amer. Acad. Vol. 17 . 

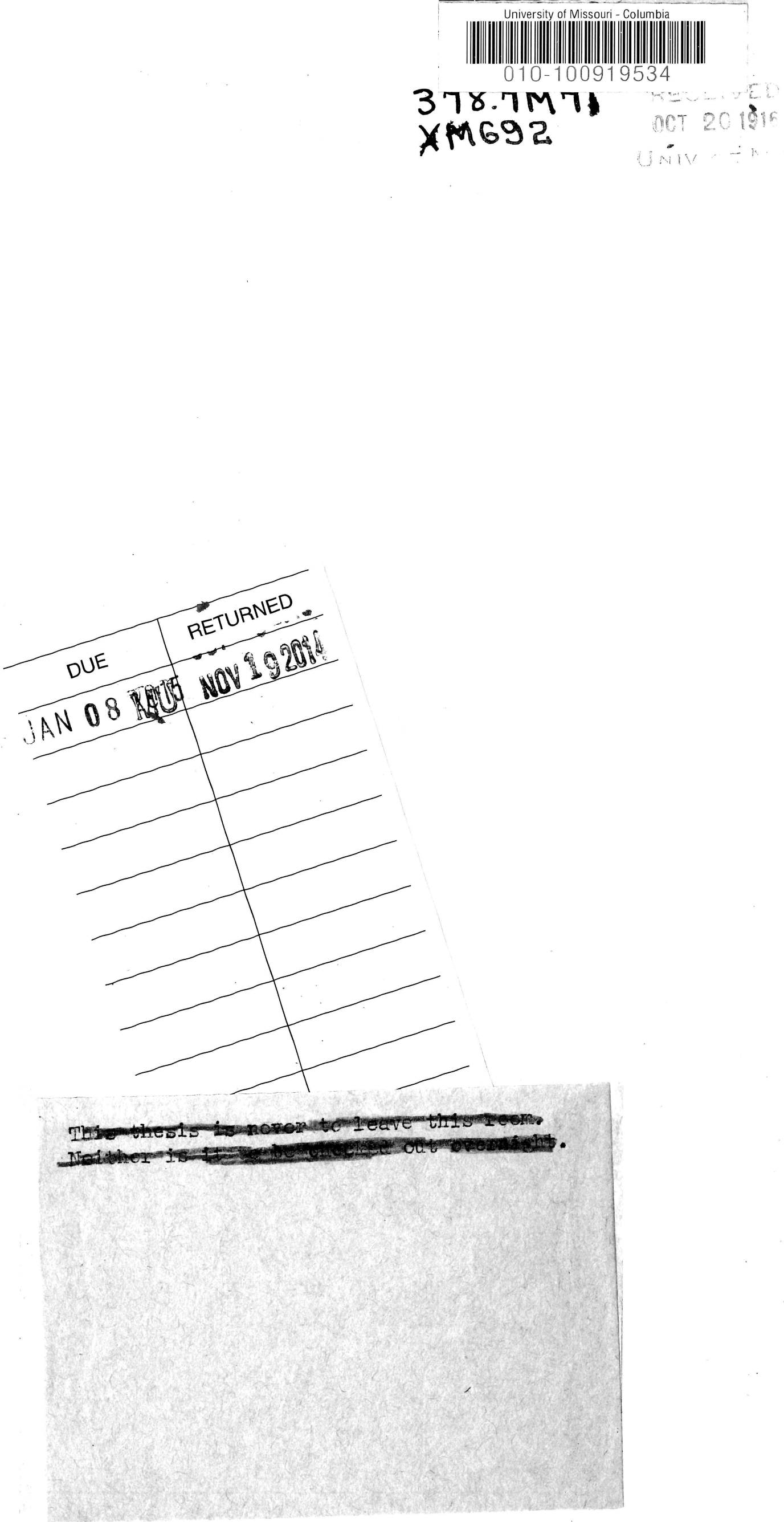
MU Libraries

Mitche11D1919specsheet. txt

University of Missouri--Columbia

MU Theses and Dissertations (Pre-1920)

Local identifier

Capture information

Date captured

Scanner manufacturer

Scanner model

Scanning system software

optical resolution

color settings

File types

Source information

Format

Content type

Source ID

Notes

Derivatives - Access copy

Compression

Editing software

Resolution

Color

File types

Notes
Mi tche11D1916

20171120

Ricoh

MP C4503

$600 \mathrm{dpi}$

grayscale

tiff

Book

Text

010-100919534

Pages typed and single-sided.

Title page has perforated property stamp.

Some pages have handwritten marginalia and corrections.

Page number 12 missing from original book. Floor plan following page 3 is folded; size is $27.5 \times 38 \mathrm{~cm}$. Paper is translucent.

Tiff compressed with LZW before conversion to pdf Adobe Photoshop CS5

$600 \mathrm{dpi}$

Grayscale

pdf

Grayscale pages cropped, canvassed, and images brightened.

Blank pages removed. 